https://doi.org/10.52837/27382702-2021-34.2-07

\title{
CHINESE BELT AND ROAD INITIATIVE IN THE COUNTRIES OF THE GULF COOPERATION COUNCIL*
}

\author{
Aghavni Harutyunyan
}

\begin{abstract}
China's relations with the Gulf Cooperation Council (GCC) countries have expanded significantly in recent years, especially in the areas of geopolitics, economics, trade, finance, banking, infrastructure, energy and security. China is deepening its economic cooperation with the GCC monarchies through the China-Arab Cooperation Forum (CASCF) and the China-GCC Framework Agreement. A mechanism that can strengthen trade relations is the FTA between China and the GCC.

The Chinese New Silk Road Initiative (NSRI) was accepted by all GCC countries that became members or perspective members of the Chinese-led Asian Infrastructure Investment Bank (AIIB). The NSRI project called "Industrial Park-Connecting ports, TwoWheel and Two-Wing Approach" would provide the basis for consolidating China-built industrial parks in key cities of the GCC with regional ports to create business clusters, increase trade flows, and connect supply chains across the region.

The future of relations between China and the GCC oil-producing countries will be based on strong, less fluid building blocks, which has facilitated alignment of the NSRI with the national development concepts of the GCC countries. All, are designed to diversify their economies from a single-resource rentier model to a post-oil model, with the necessary transition to manage their dependence on foreign labor, public sector employment and heavily subsidized utilities.
\end{abstract}

Keywords: China, GCC countries, One Belt, One Road, "Two-Wheeled" and "Two-Wing" Cooperation.

\section{Introduction}

The communist leadership of the People's Republic of China (PRC) viewed the monarchist states of the GCC $^{*}$ with deep suspicion throughout the 1950s and $1960 \mathrm{~s}^{1}$. Moreover, from 1967 to 1971 , China supported revolutionary movements in the region, but with improved relations between the PRC and the United States

\footnotetext{
* The article was submitted on November 1, 2021. The article was reviewed on November 14, 2021.

* GCC member-countries are Bahrain, Kuwait, Oman, Qatar, Saudi Arabia and the United Arab Emirates (UAE). PRC established diplomatic relations with Kuwait on March 22, 1971, with Oman on May 25, 1978, with the UAE on November 1, 1984, with Qatar on July 9, 1988, with Bahrain on April 18, 1989, with Saudi Arabia on July 21, 1990.
}

${ }^{1}$ Mashin, Yakovlev 1985: 111-112. 
(US) and increased hostility between Moscow and Beijing, China took a softer line from 1971, focusing on socialist modernization in the region instead of revolution ${ }^{1}$.

Just two days after the establishment of the $\mathrm{GCC}^{*}$, China was one of the first countries to establish links with its Secretariat on May 27, 1981. Beijing strongly supports GCC unification and regional integration and views this process as a positive contribution to the Middle East (ME) peace process, Arab unity and regional security maintaining peace and security in the Gulf region and promoting regional economic cooperation ${ }^{2}$. The six GCC countries ${ }^{*}$ pursued a neutral foreign policy of non-alignment and adopted moderate and practical measures ${ }^{3}$.

In the 1990s, after the conflict between Iraq and Kuwait, the collapse of the Soviet Union and the events in Tiananmen Square, China took a restrained position in the region, which also continued after $9 / 11 / 2001^{4}$. However, the relative decline of US hegemony and influence in the Persian Gulf (PG), the growing role of China and significant progress affect the balance of power in the region. Some Gulf States, while maintaining their strategic alliance with the US, are also seeking to establish ties with other players such as Beijing to protect themselves from the threat of regional crises or to provide security in a power struggle ${ }^{5}$.

With the growth of trade and the ever-improving structure of trade between China and the GCC countries, especially after the 1990s, a pattern of oil trading in exchange for manufactured goods and conventional finished goods such as equipment, electronics, clothing and luggage has gradually taken shape ${ }^{6}$. In 2018, the volume of trade between the Gulf countries and China amounted to about $€ 125$ billion. By 2020, the largest share of the Gulf countries' exports should have come from China - about US \$ 160 billion, with China dominating the import market, supplying goods to the PG worth about US \$ 135 billion ${ }^{7}$.

China is deepening its economic cooperation with the GCC monarchies through the China-Arab States Cooperation Forum (CASCF) and the China-GCC

\footnotetext{
${ }^{1}$ China and the Persian Gulf, Wilson Center, 12.07.2010.

* The immediate goal of the GCC was to collectively counter their security threats and defend against the threat posed by the Iran-Iraq war and Iran-inspired Islamist activism.

${ }^{2}$ Harutyunyan 2009a: 157; Batyrshin 2006: 311; The Cooperation Council for the Arab States of the Gulf (GCC), Ministry of Foreign Affairs, the People's Republic of China, 15.11.2000.

* Faced with the current new world situation, the GCC countries are increasingly showing a trend towards engaging in international and regional affairs, developing pluralistic external relations and emphasizing a balance between the major powers. In major world and regional affairs, they take a unified position and play a collective role, reflecting the unity and integrity of the foreign policy of the six countries. A customs union between the GCC was announced in 2003, and the GCC common market was launched on January 1, 2008.

${ }^{3}$ Melkumyan 2006: 97.

${ }^{4}$ China and the Persian Gulf, Wilson Center, 12.07.2010.

${ }^{5}$ Chaziza 2020a: 78.

${ }^{6}$ Mo 2011: 90.

${ }^{7}$ Molavi 2018: China and the GCC States - A Turbo-Charged Trade Relationship, The New Silk Road Monitor, October 29.
} 
Framework Agreement. A mechanism that has the potential to strengthen trade relations is the long-agreed China-Gulf Free Trade Agreement (FTA) ${ }^{1}$. FTA negotiations* were first discussed in 2004 as part of the Framework Agreement on Cooperation in Economy, Trade, Investment and Technology ${ }^{2}$. A China-GCC FTA should be based on a GCC-Singapore FTA (negotiations began in 2008 and entered into force by 2014), not only as a prelude to a broader FTA between the GCCASEAN, but also as a supplement to China's FTA ${ }^{3}$. During Xi's ME tour in 2016, the FTA gained momentum, but the ongoing dispute between Saudi Arabia, the UAE, Bahrain, Egypt and Qatar made it impossible to conclude a multilateral agreement ${ }^{4}$.

At present, the GCC countries, compared to other countries in the ME, have a high level of population welfare, high rates of economic development, political stability and certain financial capabilities. The countries of the GCC perceive China as an exemplary trading partner that does not interfere in domestic affairs, and as a great power with significant political influence in the international arena.

\section{China-GCC: Deepening Strategic Cooperation within the Belt \& Road Initiative}

In March 2015, the Chinese government released the first policy document on the "Vision and Actions on Jointly Building Silk Road Economic Belt and $21^{\text {st }}$ Century Maritime Silk Road"," outlining the format of PRC - Middle East and

\section{${ }^{1}$ China-GCC FTA, China FTA Network. http://fta.mofcom.gov.cn/topic/ engcc.shtml}

The war in Iraq and growing US dominance are pushing the GCC to conclude FTA with China in 2004.

${ }^{*}$ To date, the parties have held 5 rounds of negotiations and reached an agreement on most issues related to trade in goods. Negotiations on trade in services have also begun. A political framework must be put in place to remove barriers to trade (including services), ensure market access and investment, and promote multilateral rights to establish companies and joint ventures. The ChinaGCC FTA should also ease cooperation between State Owned and Government Related Enterprises which are dominant in both China and the GCC countries. Likewise, cooperation and joint investment between the Sovereign Wealth Funds of the two parties, which hold liquid assets in excess of US \$ 7 trillion mainly invested in Western markets and government securities, will lead to smarter investments in financing economic development in Asia/China, the ME, Africa and other emerging markets where the real returns are more promising.

${ }^{2}$ Fulton 2020: 517.

${ }^{3}$ Saidi 2014: The Gulf Should Pivot East and Build the 'New Silk Road', HuffPost News, April 15.

${ }^{4}$ Fulton 2020: 517.

* The Chinese New Silk Road (NSR/ New Silk Road Initiative (NSRI)) or One Belt, One Road (OBOR), which consists of six land and road economic corridors, is the abbreviated name of the double concept of the Economic Belt of the Silk Road (EBSR) and the Maritime Silk Road of the $21^{\text {st }}$ Century (MSR). It was launched by the Chinese President Xi Jinping in 2013 and aims to connect Asia and Europe via the Middle East (ME), Africa and Central Asia (CA) through a series of vast networks of transcontinental railways, pipelines, ports, airports, and other infrastructure projects with up to US $\$ 1$ trillion of Chinese investment. In 2016, the NSR/OBOR strategy was officially renamed the Belt and Road Initiative (BRI) or Belt and Road (B\&R). BRI will be realized through the China- 
North Africa (MENA) cooperation. In January 2016, first basic official document reflecting China's interests in the MENA, the White Paper or " $1+2+3$ " strategy, was published, which mainly covers three areas of cooperation. Within the framework of the latter, an agreement was reached between China and the Arab League member countries on the creation of China-GCC FTA and Sino-Arab Joint Investment Fund (JIF), as well as on the implementation of large projects with the AIIB participation". The "Vision and Actions" with a focus on cooperation priorities, indicates that the means by which China is already developing bilateral relations across the MENA will be coordinated with BRI. It refers to two multilateral initiatives that can foster to B\&R cooperation - the CASCF and the China-GCC Strategic Dialogue ${ }^{6}$.

The UAE and Qatar have established B\&R' JIF with China, and Saudi Arabia has signed a MoU with China to establish a BRI JIF worth US \$ 20 billion. $^{7}$ The Memorandum of Understanding (MoU) was signed during the 2017 High Level Joint Committee (HLJC) in Riyadh to develop a US \$ 20 billion JIF with the Saudi Industrial Development Fund, China's SRF and Everbright. This follows the model established with the UAE and Qatar, which have established similar, albeit smaller, foundations with Chinese organizations. The fact that both of them have gone from MoU to activation suggests that the Saudi-Saudi JIF also has the potential to be activated, and is expected to be used to develop projects related to BRI and Saudi Vision $2030^{8}$.

All GCC countries are members or perspective member (Kuwait) of the AIIB $^{9}$. Among those who have appointed a director, the second country in the ME with a representative as a director is Saudi Arabia with a share of about $2.59 \%{ }^{10}$. In

led Asian Investment Infrastructure Bank (AIIB), the Silk Road Fund (SRF) and the BRICS New Development Bank (NDB).

* 1. Energy will form the nucleus; 2. Finance and trade, infrastructure will form a "Two-Wing" strategy; 3. Science, technology (nuclear power, space satellite / aerospace technology, and renewable energy (RE) technology) and the construction of free trade zones (FTZ) and ports will form the "Two-Wheel" strategy. The "Two Wheel" energy strategy combines bilateral cooperation in the field

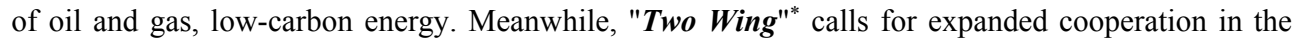
fields of science, technology and finance. The "Two Wheel" and "Two Wing" strategies will enable the establishment of business clusters in Chinese industrial parks (FTZ) in the MENA, increase trade flows and connect supply chains throughout the region.

${ }^{5}$ Harutyunyan 2021: 411-412.

${ }^{6}$ Fulton 2019b: 6 .

${ }^{7}$ Fulton 2018d: 187.

${ }^{8}$ Fulton 2020: 521.

9 The Asian Infrastructure Investment Bank (AIIB) Headquarters, Beijing. https://www.aiib.org/en/about-aiib/governance/members-of-bank/index.html

The AIIB members of GCC countries with the membership date and general subscription: Bahrain Aug. 24, 2018, US \$ 103.6 million; Oman - Jun. 21, 2016, US \$ 259.2 million; Qatar - Jun. 24, 2016, US \$ 604.4 million; Saudi Arabia - Feb. 19, 2016, US \$2,544.6 million; UAE - Jan. 15, 2016, US $\$ 1,185.7$ million.

${ }^{10}$ Fasulo, Talbot 2017: 78. 
January 2016, Chinese SRF and Saudi ACWA Power signed a MoU to jointly develop and invest in energy projects in the UAE, Egypt and other countries in the MENA, which represents the first step of SRF to investment cooperation in MENA $^{11}$. GCC funds in Kuwait, Qatar and Saudi Arabia have been prominent investors in initial public offerings (IPOs) of major Chinese banks, including China Agriculture Bank and Industrial and Commercial Bank of China (ICBC). Chinese construction companies are actively involved in the US \$ 1 trillion-dollar construction market in the Gulf countries ${ }^{12}$.

In addition, the GCC banking and financial system should be integrated into the emerging "Redback Zone" where payments, capital markets, banking and financial assets and transactions will be based on the Chinese yuan (renminbi/RMB) as an international currency. The yuan should be used for financing, clearing and settlement between ME, the GCC and China ${ }^{13}$.

The UAE has already played a role in China's efforts to internationalize the yuan and was the first GCC member to sign a swap agreement in 2012 for up to RMB 35 billion. At the end of December 2015, China extended its agreement on the exchange of the RMB with the UAE to internationalize the RMB in accordance with $\mathrm{B} \& \mathrm{R}$ guidelines for expanding the volume and scope of bilateral currency swaps and settlements with other countries in order to deepen financial cooperation, build a system of monetary stability, investment and financial system and credit information system in Asia ${ }^{14}$. Thus, the People's Bank of China (PBOC) and the UAE Central Bank have taken the first step in establishing a bilateral RMB swap line that should be extended to other GCC central banks. Given the proportionality between the trade volume and the required level of swap lines, the swap line between the Gulf countries and the RMB would be around RMB 180200 billion, given that the GCC countries account for about $2.5 \%$ of China's total trade (slightly more than in Singapore) ${ }^{15}$.

Qatar followed UAE suit in November $2014^{16}$. The ICBC launched ME's first center for clearing transactions in the Chinese yuan in Qatar in April 2015 ${ }^{17}$. The center's goal is to provide local financial institutions with access to the RMB and foreign exchange markets. It also aims to promote wider cross-border use of the RMB and expand opportunities for increased trade investment between Beijing, Doha and the region as a whole. China is trying to globalize the use of its currency

\footnotetext{
${ }^{11}$ Chen, Han 2019: 15.

${ }^{12}$ Molavi 2018: China and the GCC States - A Turbo-Charged Trade Relationship, The New Silk Road Monitor, October 29.

${ }^{13}$ Saidi 2014: The Gulf Should Pivot East and Build the 'New Silk Road', HuffPost News, April 15.

${ }^{14}$ Herlevi 2016: 14.

${ }^{15}$ Saidi 2014: The Gulf Should Pivot East and Build the 'New Silk Road', HuffPost News, April 15.

${ }^{16}$ Herlevi 2016: 14.

${ }^{17}$ Why Qatar Matters to China, in Spite of Gulf Isolation, South China Morning Post, 07.06.2017; Hollingsworth 2017: How the Gulf Row is Blocking China's New Silk Road, South China Morning Post, June 05.
} 
in order to minimize its dependence on the US dollar in the aftermath of the global financial $\mathrm{crisis}^{18}$.

The future of relations between China and the oil-producing countries of the GCC is likely to be based on solid, less "liquid" building blocks. They are undergoing major industry changes, opening up many new opportunities for Chinese investors, especially in high-tech and other emerging strategic sectors. There is a rapid growth in the information industry and renewable energy sources (RES), as well as the intention to develop the non-oil industry to reduce overdependence on oil. In this regard, China discussed BRI alignment with Saudi Arabia Vision 2030, Abu Dhabi Economic Vision 2030, New Kuwait 2035, Qatar National Vision 2030, Bahrain Economic Vision 2030, Oman Vision 2040. All of them are designed to diversify these economies from a single-resource rentier model to a post-oil model, with the necessary transition to manage their dependence on foreign labor, public sector employment and heavily subsidized utilities $^{19}$.

During the $8^{\text {th }}$ CASCF Ministerial Meeting in July 2018 (Beijing), it was announced that another project called "Industrial Park - Connecting ports, TwoWheel and Two-Wing Approach" would provide the basis for consolidating China-built industrial parks in key cities of the PG with regional ports. This will create a regional MSR network and establish a hub that will connect other important MSR regions such as South Asia and East Africa ${ }^{20}$. The Two-Wheel and Two-Wing approach will also enable Chinese industrial parks (FTZs) to create business clusters, increase trade flows, and connect supply chains across the region. It is planned to develop large industrial parks to create the above mentioned "Industrial park - port interconnection". The parties also agreed to merge longterm plans, including rail networks in the Arabian Peninsula and North Africa, to continually improve ME's ability to facilitate trade, develop industrial agglomeration, and accelerate regional development ${ }^{21}$. It is planned to combine the construction and operation of four major Chinese industrial parks in Egypt, the UAE, Saudi Arabia and Oman with neighboring ports, including the Khalifa port in Abu Dhabi, the port of Djibouti and the port of Said from Egypt and others, as part of the "Industrial Park - Port Interconnection" project ${ }^{22}$.

The Gulf Railroad Project was expected to speed up the Gulf States' connection from Kuwait to Oman via Saudi Arabia and the UAE, including branch connection to Qatar and Bahrain ${ }^{23}$. And the light rail project in Mecca (Saudi

\footnotetext{
${ }^{18}$ New Choice: Chinese Currency Expands to Middle East, Sputnik, 06.06.2015.

${ }^{19}$ Fulton 2019c: 7.

${ }^{20}$ Fulton 2019c: 2.

${ }^{21}$ Wang 2018: China and Arab States Should Jointly Forge the Cooperation Layout Featuring 'Industrial Park-Port Interconnection, Two-Wheel and Two-Wing Approach', Embassy of the PRC in the Republic of Malta, July 10.

${ }^{22}$ Harutyunyan 2021: 412.

${ }^{23}$ Wang 2017: 4.
} 
Arabia) has brought great convenience to pilgrims ${ }^{24}$. Improved infrastructure connectivity will enable China to expand its exports to the MENA and sub-Saharan Africa, thereby revitalizing regional value chains ${ }^{25}$.

It should be noted that because the PRC is highly dependent on oil and gas imports from the PG, which are delivered mainly by SLOC ${ }^{*}$ tankers and passthrough sea bottlenecks or 'Choke Points', ' the forced cessation of energy imports in adverse conditions can quickly paralyze the PRC's economy and military forces $^{26}$. In this regard, the creation of the "Gulf String of Pearls" will significantly reduce Beijing's dependence on SLOC and facilitate economic integration between West Asia, Southeast and East $\mathrm{Asia}^{27}$. It could greatly reduce Beijing's dependence on maritime communications, fostering economic integration processes between the West, South East and East Asia.

Meanwhile, this undoubtedly could raise concerns in the West, India and other regional players about China's growing influence in the Indo-Pacific region, fearing that China-backed civilian and port facilities will regularly be used by China's naval forces as the hub in the "String of Pearls" strategy ${ }^{28}$.

\section{China - GCC: "Two-Wheel" and "Two-Wing" Strategy}

SAUDI ARABIA: China and Saudi Arabia are considered natural partners for B\&R collaboration, as Saudi Arabia is an important link between China and the hinterland of Eurasia, as well as an important crossroads linking China to the vast African market ${ }^{29}$.

During President Xi's visit to Saudi Arabia in January 2016, China and Saudi Arabia decided to establish a joint committee - a comprehensive, high-level institutional platform for cooperation between the governments of the two

${ }^{24}$ Spotlight: China's 'Belt and Road' Initiative Boosts Mideast Development, English.news.cn, 19.01.2016.

${ }^{25}$ Ekonomika Odnogo Poyasa, Odnogo Puti. Vozmozhnosti i riski transportnykh koridorov. 2020: [Economy of One Belt, One Road. Opportunities and Risks of Transport Corridors], World Bank Group, Washington DC, 61-62.

${ }^{*}$ Shipping lines, also known as Sea Lines of Communication (SLOCs) are the sea routes between ports.

* Maritime "Choke Points" are naturally narrow channels of shipping having high traffic because of their strategic locations. Maritime chokepoints, or oil chokepoints, are congestive pathways in some of the world's famous shipping routes. There are many such chokepoints around the world, however, a few of them are extremely famous for ships and thus face high international security conflicts and cross-border terrorism threats.

${ }^{26}$ Lokhande 2017: China's One Belt One Road Initiative and the Gulf Pearl Chain, China Daily, June 05 .

* MSR's strategy is noteworthy in that it focuses on the creation of Chinese strongholds or "naval posts" with military or geopolitical influence along the coast of the Indian Ocean, in the PG and the Mediterranean Sea, called the "String of Pearls" - similar to the "Dual Use Logistics Facility".

${ }^{27}$ Harutyunyan 2020: 60-67.

${ }^{28}$ Harutyunyan 2019: 147.

${ }^{29}$ Juan, Meng, Wen 2018: 367. 
countries. Its main task is to implement the important consensus reached by the heads of state, as well as to coordinate and promote cooperation in various fields. Seven subcommittees ${ }^{*}$ chaired by deputy ministers were established by the ChinaSaudi Arabia High-Level Joint Committee, and the Fiscal and Finance Subcommittee was established in $2019^{30}$.

In April 2016, Saudi Arabia announced its Vision 2030 National Economic Reform Plan, which was formally presented at the 2016 G20 Summit in Hangzhou (China), by Saudi Crown Prince Mohammed bin Salman ${ }^{31}$. Riyadh wants to fundamentally transform its economy into a "normal" one over the next 15 years, and the only way to approach this is through Chinese investment in the real sector (commercial, manufacturing) of the economy ${ }^{32}$.

In March 2017, during the visit of the King of Saudi Arabia to China, President Xi formally expressed his support for Saudi Arabia's implementation of Vision 2030, as well as its willingness to contribute to the diversified economy of Saudi Arabia, which was later recorded in the "Joint Statement of the People's Republic of China and the Kingdom of Saudi Arabia"33. The parties signed an agreement worth almost US \$ 65 billion $^{34}$ and created a high-level joint commission to promote the BRI and Vision 2030 alignment $^{35}$.

On 31 August 2016, during the first meeting of the China-Saudi High-Level Committee in Beijing, Yinchuan Yucheng, Guangzhou Hi-tech District Investment Group, the Royal Commission for Jizan and Yanbu (referred to as the 'Royal Commission') and Saudi Aramco signed a framework agreement for the establishment of a joint venture company in Jizan Basic Industrial City ${ }^{36}$.

Saudi Jizan City for Primary and Downstream Industries (JCPDI) is being developed as part of the BRI-Saudi Arabia strategic partnership Vision 2030 between China and Saudi Arabia. In 2016, the Royal Commission for Jubail and Yanbu (RCJY), Saudi Aramco, and Guangdong and Ningxia provinces agreed to establish a joint venture company Saudi Silk Road Industrial Services in JCPDI. It will focus on attracting Chinese investments and providing industrial services in a $32 \mathrm{~km}^{2}$ special development zone, including a $30 \mathrm{~km}^{2}$ industrial zone with no fixed physical boundaries and a $2 \mathrm{~km}^{2}$ residential area with closed management under the JCPDI. It is designed to accelerate the Kingdom's industrialization process by

\footnotetext{
* Politics and Foreign Affairs, BRI and Major Investment Cooperation Projects, Energy, Trade and Investment, Culture, Science and Technology, Tourism, Military and Security Cooperation.

${ }^{30}$ Zishi, Le, Liping 2020: 530.

${ }^{31}$ Juan, Meng, Wen 2018: 364.

32 Korybko 2017: Why is China Choosing to Partner with Israel and Saudi Arabia? The Duran, March 25.

${ }^{33}$ Juan, Meng, Wen 2018: 367.

${ }^{34}$ King's Visit to China Reflects Saudi Arabia's Position Globally, Experts Say, Arab News, 19.03.2017.

${ }^{35}$ Juan, Meng, Wen 2018: 364.

${ }^{36}$ Zishi, Le, Liping 2020: 533.
} 
integrating the technology, manufacturing capabilities and investment resources of two Chinese partners from Guangdong and Ningxia provinces. Jizan is strategically located and equipped with world-class infrastructure connecting European, African and Middle Eastern markets. Guangzhou-based Pan-Asia PET Resin, one of the three largest PET bottle suppliers in China, pioneered the project and said it plans to invest US \$ 3.8 billion to build a polyester complex in Jizan. In March 2017, RCJY signed an agreement with Pan-Asia PET Resin to allocate industrial land for a petrochemical plant in Jizan and pledged to provide funds from the Saudi Industrial Development Fund ${ }^{37}$.

According to the industrial layout plan of Jizan Basic Industrial City, there are heavy industrial, manufacturing and light industries, residential areas and commercial areas from south to north. As for the heavy industry, it will focus on the development of power plants, seawater treatment plants, fuel storage facilities, etc. Light industry will focus on the development of raw materials, electronic products, advanced services, garbage disposal, industrial components, biotechnology and agricultural technology. From 2018 to 2020, China's Enterprise Special Development Zone will focus on the introduction of the steel, petrochemical, silicon and shipbuilding industries. From 2020 to 2025, it will oversee the development of the food and packaging industry, the assembly of household appliances, mechanical and electrical equipment, and building materials ${ }^{38}$.

Another BRI-Vision synergy is the "most ambitious project in the world" and a US $\$ 500$ billion smart city on the northwest coast of the Red Sea - the Saudi metropolis of Neom, which will be completed in 2025. It will open up significant opportunities for contract infrastructure and ensure the successful operation of Chinese firms in the kingdom for years to come ${ }^{39}$. The city will be bigger than Dubai and it will have more robots than people. In the center of the city there will be developed industries, biotechnology, media and airlines, everything will be connected with artificial intelligence, with the Internet of Things. Crown Prince Mohammed bin Salman said the sci-fi city with gleaming office towers and fivestar hotels should reflect Saudi Arabia's efforts to transform a nation that was once bathed in oil money and is now facing serious financial problems ${ }^{40}$.

China Global Investment Tracker estimates the value of Chinese construction contracts in Saudi Arabia between 2005 and 2019 at over US \$ 35 billion, of which nearly US \$ 1.1 billion comes in since 2007. Among the projects were some highprofile ones, such as the participation of the China Railway Construction Corporation in the construction of the Mecca-Medina-Jeddah railway to transport pilgrims during the Hajj, the construction by the China Energy Corporation of the

\footnotetext{
${ }^{37}$ Chen, Han 2019: 24.

${ }^{38}$ Zishi, Le, Liping 2020: 534.

${ }^{39}$ Fulton 2020: 522.

${ }^{40}$ Carey, Nereim, Cannon 2017: Sun, Sea and Robots: Saudi Arabia's Sci-Fi City in the Desert, Bloomberg, October 26.
} 
largest power plant in the ME north of Jeddah, and the joint construction of Aramco-SINOPEC refinery in Yanbu ${ }^{41}$. In December 2019, the China Civil Engineering Corporation and the Government of Saudi Arabia signed a framework cooperation agreement on the Saudi Mainland Bridge Railway project, which is designed for $1000 \mathrm{~km}$ and will become the main artery of the railway upon completion $^{42}$.

However, while most Chinese media outlets have a positive view of Saudi Arabia's Vision 2030, they also express concern that, despite its simple formulation, such a program is difficult to implement due to structural problems that impede economic diversity and the inability to secure their revenues without relying on oil until at least $2020^{43}$.

UAE: To integrate the UAE, China wants to combine its " $B \& R$ westward" strategy with the UAE's "Look East" policy, which aims to increase the UAE's share of trade and investment from emerging Asian economies in an effort to diversify the local economy. As the third largest re-export center in the world after Singapore and Hong Kong, approximately $60 \%$ of China's trade passes through the JAFZA in Dubai, the largest in the world, from where it is re-exported to Africa and Europe ${ }^{44}$.

Abu Dhabi (the UAE capital) also intends to build a "sustainable economy" as part of a key energy security strategy for the future, diversifying its economy from oil dependence and supporting the development of tourism, manufacturing, healthcare, petrochemicals, financial services and $\mathrm{RE}^{45}$. Energy diversification is in line with AIIB's proposed "lean, clean, and green" approach, and Abu Dhabi believes that Beijing can strengthen the UAE as a key player and architect of the GCC's energy future ${ }^{46}$. The $100 \mathrm{~km}^{2}$ Khalifa Port FTZ (KPFTZ) is an important part of the Abu Dhabi Economic Vision 2030 diversification program, scheduled for completion in 2030, with the port and FTZ combination expected to ultimately provide $15 \%$ of Abu Dhabi's non-oil GDP ${ }^{47}$.

The partnership between the UAE and the PRC rests on a fairly solid foundation, primarily in the field of finance and investment. In December 2015, China and the UAE established a US \$ 10 billion joint investment fund to finance energy and high-tech projects. ICBC, China Construction Bank (CCB), Agricultural Bank of China (ABC) and Bank of China (BOC) operate in the Emirates. In 2016, UAE investors poured over US \$ 2.1 billion in China, while China's foreign direct investment (FDI) in the UAE totaled US $\$ 4.6$ billion. The

\footnotetext{
${ }^{41}$ Fulton 2020: 521.

${ }^{42}$ Zishi, Le, Liping 2020: 530.

43 Juan, Meng, Wen 2018: 367-368.

${ }^{44}$ Scott 2015: 12-15.

${ }^{45}$ Shepard 2017: Next Up on China's Maritime Silk Road: Abu Dhabi, Forbes, July 02.

${ }^{46}$ Herlevi 2016: 15.

${ }^{47}$ Shepard 2017: Next Up on China's Maritime Silk Road: Abu Dhabi, Forbes, July 02.
} 
volume of trade between the countries at the end of 2017 amounted to more than US \$ 41 billion $^{48}$.

Chinese state-owned enterprises and multinationals are well represented in the JAFZA, serving contracts throughout the Arabian Peninsula and MENA in general. Dubai is home to a sizable Chinese community, ranging from 200,000 to 300,000, with over 4,000/4,500 Chinese enterprises and companies operating there ${ }^{49}$. With the growing participation of China in Africa, more and more businessmen travel to the African continent, using Dubai as a transit point ${ }^{50}$.

Strategically located between the West and the Far East, as well as between Europe, Russia and Africa, the UAE's geography, dynamic economy, political stability and advanced logistics infrastructure have made Abu Dhabi and Dubai invaluable trading hubs connecting BRICS members. ${ }^{*}$ The UAE has played a key role in connecting China and Russia to the "Global South"51.

In October 2016, China invested approximately US \$ 2.3 billion in the UAE, in infrastructure such as the Jebel Ali port, offering China access to a key international transport hub ${ }^{52}$. In the same year, the Abu Dhabi Port (ADP) signed a contract with China Ocean Shipping (Group) Company (COSCO Group), the world's largest container operator, which chose the port of Khalifa as a hub for its ME operations and is expected to increase its annual capacity to 6 million TEU (Twenty-foot Equivalent Unit) at both existing container terminals. ${ }^{53} \mathrm{COSCO}$ has invested US \$ 400 million in the construction of a container terminal at ADP to support the expected increase in trade flows along the B\&R routes ${ }^{54}$.

In 2017, the Khalifa Industrial Zone Abu Dhabi (KIZAD) - designated KPFTZ $^{*}$ and Jiangsu Overseas Cooperation and Investment Company (JOCIC) ${ }^{*}$ has established a China-UAE Industrial Capacity Construction Management

48 Kitay rasshiryayet vliyaniye na Blizhnem Vostoke i zakreplyayetsya v Afrike [China Expands Influence in the Middle East and Consolidates in Africa], Informatsionnyy portal Fars News - Forum Korrespondentov Irana, Tsentral'noy Azii i Rossii, 23.07.2018.

${ }^{49}$ Fulton 2019a: 2; Miles, Edwards: 5.

${ }^{50}$ Dos Santos 2015: 2.

${ }^{*}$ Brazil, Russia, India, China and South Africa.

${ }^{51}$ Karasik 2018: Chinese President's Visit to the UAE and Africa Demonstrates a Shift in the New World Order", Arab News, July 29.

52 Blanche 2017: China's New Silk Road Includes Both Risk and Promise of Prosperity. The Arab Weekly, December 17.

${ }^{53}$ Lee 2017: Abu Dhabi Ports Inks \$300m Investment Cooperation with China, Seatrade Maritime News, July 21.

${ }^{54}$ Hollingsworth 2017: How the Gulf Row is Blocking China's New Silk Road, South China Morning Post, June 05.

* KPFTZ is the second busiest port in the UAE after Dubai.

* Consortium of five companies: Hanergy Thin Film Power Group, Jiangsu Fantai Mining Development (Group) Co, Xuzhou Jianghe Wood, Jiangsu Jinzi Environmental Technology, and Guangzheng Group. 
Company and invested US $\$ 1.1$ billion in the port of Khalifa ${ }^{55}$. At the end of June 2017, as part of the BRI, the Chinese province of JOCIC signed a US \$ 300 million agreement with the ADP in the $\mathrm{UAE}^{56}$, to create more than 1,400 jobs and to develop manufacturing activities in the KPFTZ ${ }^{57}$.

The land allotted for Jiangsu province's activities is only $2.2 \%$ of the available land in the FTZ. The goal is for Port Khalifa and the FTZ to become transnational transport, manufacturing and trade centers, which are designed to attract investment from around the world, not just China ${ }^{58}$. The land lease includes an option for China-UAE Industrial Capacity Cooperation (Jiangsu) Construction Management to establish and develop a further 107,639,100 square feet of FTZ at KIZAD Area B to meet additional demand by Jiangsu province businesses. As part of the agreement, a 50-year Musataha agreement was signed by the ADP with $\mathrm{JOCIC}^{59}$.

In 2018, twelve Chinese companies agreed to invest over US \$ 800 million in the B\&R project in Abu Dhabi, creating over 2,000 jobs. The companies, 10 of which are located in Jiangsu province in eastern China, have signed agreements with $\mathrm{JOCIC}^{60}$. In September 2018, JOCIC hosted an investment promotion conference, inviting a delegation from the ports of KIZAD and Abu Dhabi to Nanjing, where they met with over 180 representatives of Chinese government agencies and 90 representatives of Chinese companies to showcase the investment opportunities $^{61}$.

East Hope Group, one of China's largest companies, announced in May 2018 that it is considering investing US $\$ 10$ billion in KIZAD in three stages over 15 years. East Hope and Emirates Global Aluminum (EGA) are among the world's largest aluminum producers. The Abu Dhabi Mubadala Sovereign Wealth Fund, which is jointly owned by EGA, has partnered with Chinese institutions in a coinvestment fund to benefit from projects in the UAE and China that support the BRI and the Abu Dhabi Emirate 2030 Development Plan ${ }^{62}$.

In April 2019, the UAE and China signed new deals worth US \$ 3.4 billion under the BRI, which could boost bilateral trade by US $\$ 53$ billion to US $\$ 70$ billion by 2020. As part of the new deals, the two countries have made a number of

\footnotetext{
${ }^{55}$ Fulton 2019a: 2; Lee 2017: Abu Dhabi Ports Inks \$300m Investment Cooperation with China, Seatrade Maritime News, July 21.

${ }^{56}$ Shepard 2017: Next Up on China's Maritime Silk Road: Abu Dhabi, Forbes, July 02.

${ }^{57}$ Lee 2017: Abu Dhabi Ports Inks \$300m Investment Cooperation with China, Seatrade Maritime News, July 21.

${ }^{58}$ Shepard 2017: Next Up on China's Maritime Silk Road: Abu Dhabi, Forbes, July 02.

${ }^{59}$ Lee 2017: Abu Dhabi Ports Inks \$300m Investment Cooperation with China, Seatrade Maritime News, July 21.

${ }^{60}$ Capturing the Opportunities from Belt and Road Initiative. 2018: 22.

${ }^{61}$ Fulton 2019a: 2.

${ }^{62}$ Ibid.: 2.
} 
new investments, including the construction of a 60 million square foot station on the NSR in Dubai for EXPO $2020^{63}$.

In 2018, the Civil and Infrastructure Division of China State Construction and Engineering Corporation Middle East (CSCEC/CSCME) has obtained the Letter of Acceptance from RTA (Road and Transportation Authority) for R1086 Dubai Hills Estate Mall Access and Umm Suqeim Street Upgrading project worth AED (UAE Dirham) 800 million (US \$ 218 million) ${ }^{64}$.

In the Gulf of Oman in 2014, the only fully operational private container terminal in the UAE, Khorfakkan Container Terminal (KCT), received the first ship of the China Shipping Container Lines (CSCL) with the United Arab Shipping Company (UASC), co-owned by the UAE, Kuwait, Bahrain, Saudi Arabia, Qatar and Iraq. The two carriers have signed a series of joint service agreements connecting Asian ports with ports in the ME and Europe. In addition to the Far East - Middle East route, it will serve the Jebel Ali-Tianjin trade route, which is the busiest route between the Far East and the Gulf region. Since 2001, CSCL has also partnered with Dubai Ports (DP) World, a global port terminal operator that was formerly the Dubai Port Authority and is now the international division of JAFZA. Showcasing the importance China attaches to its maritime trade with the UAE, the seventh of CSCL's recently acquired 14,000 TEU container ships also made its first call at Jebel Ali Port, located at the western end of the Free Zone bordering the Emirate of Abu Dhabi. In addition to the Far East-ME route, it will serve the Jebel Ali-Tianjin trade route, which is the busiest route between the Far East and the Gulf region ${ }^{65}$.

In 2014, a strategic framework agreement was announced between Qingdao Port Group and DP World, further deepening the existing partnership. The agreement focused on continued cooperation in Jebel Ali Port (a port city $35 \mathrm{~km}$ southwest of Dubai), DP World base port and Mina Rashid port located in the eastern part of Jebel Ali zone near the Emirate of Sharjah. Another goal is to connect the two ports with a railway that will run through the JAFZA, adding another aspect of multimodal connectivity for Chinese exporters so that they can use the UAE as a distribution hub in the Gulf region ${ }^{66}$. The port is an important access point for China's efforts to create smooth, safe and efficient transport routes connecting major seaports along the $\mathrm{B} \& \mathrm{R}^{67}$.

However, there are also opinions that, despite the UAE's "Look East" policy, the Emirates have their own corporations integrated into the global economy, and the feasibility of China's plans to include the UAE in its BRI has some limitations.

\footnotetext{
${ }^{63}$ Murphy 2019: The UAE Signed a Massive, \$3.4 billion Deal with China - and That 'Isn't a Surprise', CNBC, April 29.

${ }^{64}$ Capturing the Opportunities from Belt and Road Initiative. 2018: 23.

${ }^{65}$ Scott 2015: 12-15.

${ }^{66}$ Ibid.: 12-15.

${ }^{67}$ Herlevi 2016: 14.
} 
Locally, it describes how Chinese companies focus only on exports and imports and want government contracts without being tied to the local market and culture $^{68}$

QATAR: Qatar's National Vision 2030 (QNV2030) is a shared vision and roadmap for transforming Doha (capital of Qatar) into a progressive society capable of sustainable development and a high standard of living for all citizens by 2030. By identifying long-term results for Doha, it provides a framework for the development of national strategies and implementation plans, assists Qatari government strategies, policies, planning and allocation of funds and resources to achieve a common goal. It also provides private sector companies and, to some extent, individuals with a shared direction and purpose ${ }^{69}$. QNV2030 envisions development in four interrelated areas: human, social, economic and environmental development ${ }^{70}$.

Beijing views Qatar as an important partner in advancing the B\&R project, especially with its economic and geographic components that play a vital role in the creation of China - the GCC FTA. And deeper Sino-Qatari cooperation could improve the prospects for QNV2030 and help it break out of diplomatic and economic isolation ${ }^{71}$. The side wants to strengthen the BRI's integration with Qatar's QNV2030 strategy, creating the "four pillars" of pragmatic cooperation between China and Qatar, including energy, infrastructure, financial investment and high technology ${ }^{72}$.

In 2015, Qatar's exports totaled US \$ 5.24 billion and imports US \$ 3.7 billion $^{73}$. The volume of trade between China and Qatar is increasing year by year, reaching US \$ 11 billion in 2019. Cooperation between China and Qatar has formed a mature model in which energy is the backbone, infrastructure is key, and finance and investment is a new starting point ${ }^{74}$. There are currently more than 14 wholly-owned Chinese companies operating in Qatar, in addition to 181 QatariChinese joint ventures. China is an attractive destination for Qatari investments in shipbuilding, manufacturing, petrochemicals, technology, hospitality, tourism and financial services, as well as other vital industries. Qatar also allows foreign investors $100 \%$ ownership in various sectors and industries ${ }^{75}$.

\footnotetext{
${ }^{68}$ Scott 2015: 12-15.

${ }^{69}$ Qatar National Vision 2030. 2008: 11.

${ }^{69}$ Chaziza 2020b: 83.

${ }^{70}$ Qatar National Vision 2030. 2008: 11.

${ }^{71}$ Chaziza 2020b: 79.

${ }^{72}$ He 2020: Qatar and China Natural Partners in Belt and Road Cooperation. The Peninsula, June 30.

${ }^{73}$ Hollingsworth 2017: How the Gulf Row is Blocking China's New Silk Road, South China Morning Post, June 05.

${ }^{74}$ China and Qatar are Natural Partners in Belt and Road Co-Operation: Envoy, Gulf Times, 29.06.2020.

${ }^{75}$ Chaziza 2020b: 86.
} 
In April 2017, the Chamber of Qatar and the China Council for the Promotion of International Trade signed an agreement to develop cooperation relations between the two parties in order to maximize the benefits for the private sector of Qatar and China (private entrepreneurs), and also signed a MoU for the entry of the Qatar Chamber into the Silk Road Chamber of International Commerce. In November 2018, the parties signed a MoU to identify global maritime investment opportunities that will serve both QNV2030 and BRI ${ }^{76}$.

In 2014, Chinese companies signed agreements to participate in the construction of infrastructure projects worth US \$ 8 billion in Qatar. Projects include construction works, building roads, bridges, ports, and strategic water reserves and telecommunications infrastructure. After Qatar was selected to host the 2022 FIFA World Cup, China Railway Construction Corp won the contract to build Lusail Stadium for the event ${ }^{77}$. China's largest telecommunications equipment company Huawei also contributed to the creation of the first commercial 5G networks in Qatar. The parties will also expand cooperation in the field of high technologies, in such projects of Qatar as big data, smart railways, as well as in the development of the digital economy and smart cities ${ }^{78}$.

Financial investments and cooperation in the field of high technologies are new growth points. BOC and ICBC are the two largest financial subsidiaries of Qatar Free Zones Authority (QFZA) in terms of total assets, providing over $70 \%$ of loans to support local businesses ${ }^{79}$. QFZA is positioning itself as one of the catalysts for the growth of Qatar's BRI, opening doors to potential investors in both Qatar and China. In 2019, under BRI, QFZA signed four separate MoUs with the China Council for the Promotion of International Trade (CCPIT), Xiamen FTZ, Shenzhen Cross-Border Electronic Commerce Association and China Harbor Group. Currently, China Harbor is implementing a green energy bus assembly plant at QFZ, as well as a ship crane project ${ }^{80}$.

BAHRAIN: In October 2008, King Hamad bin Isa Al Khalifa of Bahrain presented the Economic Vision 2030, which focuses on shaping a vision of government, society and the economy based on three guiding principles: sustainability, fairness and competitiveness, so that every Bahraini has the means to live a safe and fulfilling life and realize its full potential. Bahrain seeks to move from an oil-based economy to a productive, globally competitive economy driven by government and an innovative private sector - an economy that fosters Bahrain's broad middle class, enjoying a good standard of living through productivity gains

\footnotetext{
${ }^{76}$ Ibid.: 84 .

${ }^{77}$ Why Qatar Matters to China, in Spite of Gulf Isolation, South China Morning Post, 07.06.2017.

${ }^{78}$ He 2020: Qatar and China Natural Partners in Belt and Road Cooperation. The Peninsula, June 30.

${ }^{79}$ Ibid.

${ }^{80}$ Shoeb 2019: Belt \& Road Initiative to Bring Qatar and Mideast Closer to the World: QFZA Chief, The Peninsula, November 04.
} 
and high-paying jobs ${ }^{81}$. By 2030, Bahrain intends to fully connect with the world's trade and information highways, using public and private funds to create and maintain the necessary infrastructure and services ${ }^{82}$.

Bahrain's strategic location in the heart of the PG makes accessibility and access to any market in ME (land, sea or air) fast and economically viable. Khalifa bin Salman Port (KBSP), a major transshipment hub in the North Gulf, has boosted the country's role as a major supplier of goods to Saudi Arabia. The strategic location of KBSP in the middle of the PG, together with its deep-water berths and approach channel, receiving the largest ocean-going container ships, and its direct land connections to the mainland (Saudi Arabia and Qatar) make the port a major regional distribution center ${ }^{83}$.

Bahrain International Airport, which is undergoing an extensive expansion and modernization program to enhance the country's status as a tourist destination and logistics center by 2020, can be considered a major regional transport hub and a good location for order fulfillment centers for Chinese companies operating on the $\mathrm{NSR}^{84}$. Several large Chinese companies, including Huawei Technologies, CPIC Abahsain Fiberglass, China Machinery Engineering Corporation and China International Marine Containers Company (CIMC), have invested in Bahrain. In 2009, Huawei moved its headquarters to Bahrain and is currently building and accelerating the Kingdom's $5 \mathrm{G}$ mobile network ecosystem ${ }^{85}$.

KUWAIT: In 2010, the Kuwait government issued Kuwait 2035, or Kuwait's National Development Plan, formulated with the goal of transforming the country into a regional financial center by 2035 through 164 strategic development projects. In such circumstances, the BRI gave Kuwait a chance to optimize its economic structure and could align well with the country's national development strategy $^{86}$.

In 2017, the Kuwait's Directorate-General for Civil Aviation (DGCA) awarded a contract with a joint venture between China's AVIC International Holding Corporation and local Al-Dar (HOT) Engineering and Construction to build a new runway and expand the existing runway at Kuwait International

\footnotetext{
${ }^{81}$ Bahrain Economic Vision 2030, Ministry of Industry, Commerce and Tourism, Kingdom of Bahrain. https://www.moic.gov.bh/en/Ministry/bahrain-economic-vision-2030

${ }^{82}$ From Regional Pioneer to Global Contender: The Economic Vision 2030 for Bahrain, Bahrain.Bh. https://www.bahrain.bh/wps/wcm/connect/38f53f2f-9ad6-423d-9c962dbf17810c94/Vision\%2B2030\%2BEnglish\%2B\%28low\%2Bresolution\%29.pdf?MOD=AJPERES

${ }^{83}$ Chaziza 2020a: 74.

${ }^{84}$ Ibid.: 74.

${ }^{85}$ Chaziza 2020a: 75.

${ }^{86}$ Spotlight: Belt and Road Set to Boost Development in Mideast, Africa, Xinhua Net, 24.08.2017.
} 
Airport. The team offered 149.8m KWD (Kuwaiti dinar / US \$ 492 million) for the contract and the project was expected to be completed in $2020^{87}$.

Kuwait plans to invest US $\$ 130$ billion in the construction of the northern Silk City or a new business center commonly known as Madinat al-Hareer, which will help connect Europe and Asia along the Silk Road (SR) ${ }^{88}$. It is expected to be completed by 2035 in northern Kuwait and will be a major new stop on the Ancient Silk Road (ASR) trade route. The Silk City with a 1001-meter skyscraper in its master plan will be jointly developed by Kuwaiti and Chinese enterprises as part of China's BRI program. The $36 \mathrm{~km}$ Sheikh Jaber Causeway project connecting Silk City and Kuwait is already under construction ${ }^{89}$. Located in Kuwait's northern coastal region of Subiya and on Bubiyan Island, which stretches for $1,140 \mathrm{~km}^{2}$, the city will become an important strategic junction connecting China and Europe on the NSR ${ }^{90}$.

OMAN: Oman is located in the southeastern part of the Arabian Peninsula and is the center for the distribution of goods between East and West. Muscat (the capital of Oman) is of great importance for the maritime traffic between Oman and other countries of the $\mathrm{PG}^{91}$. In addition to Oman's strategic geographic location, its relatively flexible investment policies, FTZs and consumer markets are attracting Chinese investors, and its ties to Oman provide China with a platform to expand its influence in $\mathrm{ME}$ as a whole and revive ancient trade contacts under the auspices of its $B \& R^{92}$. It is worth noting that Oman's geographic location puts it in close proximity to other areas of central concern for China, including Djibouti, Somalia and vast expanses of East Africa, Iran, Pakistan, India and the Indian Ocean. Oman's influence as a maritime and imperial power extended beyond the Arabian Peninsula and the PG to the coastal regions of East Africa and Gwadar in Baluchistan in Pakistan - all areas that would be linked by MSR ${ }^{93}$.

Oman's 2040 Vision aims to reduce dependence on non-renewable energy sources and efficiently develop resources such as renewable energy sources to reduce production costs and increase competitiveness in economic sectors, infrastructure development and human capacity building for Omanis ${ }^{94}$. It has 3 main pillars: people and society, economy and development, governance and

\footnotetext{
${ }^{87}$ Capturing the Opportunities from Belt and Road Initiative. 2018: 23; Aguinaldo 2017: Kuwait Awards Runway Construction Package, Middle East Business Intelligence (MEED), March 29.

${ }^{88}$ Huang 2017: Qatar Crisis Poses Test for China's Belt \& Road Project, Voice of America (VOA), June 08 .

${ }^{89}$ Spotlight: China's 'Belt and Road' Initiative Boosts Mideast Development, English.news.cn, 19.01.2016.

${ }^{90}$ Wu 2015: 1.

${ }^{91}$ Al Saadi 2012: 85.

92 Rakhmat 2014: Exploring the China and Oman Relationship. The Diplomat, May 10.

${ }^{93}$ Zambelis 2015: 12-13.

${ }^{94}$ Kazem, Chaichan, Al-Waeli, Bin Sopian 2020: 1.
} 
institutional performance ${ }^{95}$.

The Omani government has responded positively to China's invitation to collaborate on MSR projects as investment and trade fit into infrastructure, financing and capacity building, supporting the restructuring of Oman's economy. Oman needs Chinese investment to provide the reliable logistics and infrastructure links needed to meet the refining and marketing diversification goals set out in its Vision 2020 strategy to diversify its oil and gas economy. Omanis will welcome China's growing investment due to the economic woes of low oil prices as well as the serious problem of youth unemployment ${ }^{96}$.

According to the AIIB website, two of the nine projects that have received approval are located in the ME, in particular in Oman, and are categorized as "sector: transport". The first one is the Duqm Port Commercial Terminal and Operational Zone Development Project, with an estimated cost of more than US \$ 353 million and $75 \%$ funded by AIIB (US $\$ 265$ million). The second is the Railway System Preparation Project, which will cost US \$ 60 million, 60\% of which will be financed by AIIB (US \$ 36 million) ${ }^{97}$. In 2016, AIIB provided US \$ 300 million in funding to expand the port of Duqm in Oman and launch the first rail system in the Sultanate ${ }^{98}$. In Oman, PRC's investment can account for more than half of all FDI ${ }^{99}$.

Oman Wanfang, a consortium of six private firms primarily from the China's northwestern Ningxia Hui Autonomous Region, was named by Special Economic Zone Authority at Duqm (SEZAD) in April 2017 as the main developer of the 1,200 -hectare venture in the coastal city. Duqm is a fishing village about $550 \mathrm{~km}$ south of the capital Muscat, an industrial city that will complement the strategic port $^{100}$. It is planned that the Sino-Omani industrial park will include about 35 projects worth about US $\$ 10.7$ billion $^{101}$. It includes a refinery, a methanol plant, steel pipe plants, an automobile assembly plant, an energy project, a solar energy project and a five-star hotel with a combined investment to date of over US \$ 3 billion $^{102}$.

Duqm SEZ is located along the Arabian Sea coastline with a length of 3,100 $\mathrm{km}$, providing an access point for energy carriers of the PG bypassing the Strait of

\footnotetext{
${ }^{95}$ Oman Vision 2040, Omanuna: The official E-Government Services Portal. https://omanuna.oman.om/en/home-top-level/eparticipation/oman-vision-2040

${ }^{96}$ Chaziza 2019c: 48.

${ }^{97}$ Fasulo, Talbot 2017: 77-78.

${ }^{98}$ China's 'Belt and Road' Offers Middle East Opportunities Galore, Ameinfo.com, 19.06.2017.

${ }^{99}$ Wang 2018: China's One Belt, One Road Initiative, SOAS University of London, June 01.

${ }^{100}$ Bhaya 2018: Analysis: Could China-funded Omani Port Go against Beijing's Interest? CGTN, February 27.

${ }^{101}$ In Its Promotional Campaign in China, Duqm Focuses on Attracting New Industrial Companies, SEZAD - Sultanate of Oman, 24.09.2018.

102 Bhaya 2018: Analysis: Could China-funded Omani Port Go against Beijing's Interest? CGTN, February 27; Molavi 2018: Enter the Dragon: China's Belt and Road Rising in the Middle East, The Caravan, Issue 1819, Hoover Institution or Stanford University, October 02.
} 
Hormuz, designed to redirect traffic from the PG and reconfigure the current Indian Ocean sea routes ${ }^{103}$. It is one of the largest in the MENA region and one of the largest in the world. It is conceived as an energy hub, as well as an industrial and commercial center. This promising industrial hub, home to a world-class seaport and shipyard, as well as a multimodal transportation system including highways, airports, seaports and high-speed railways (in the future), is centrally located to facilitate integration and ease movement not only within Duqm, but also connecting it nationally, regionally and internationally ${ }^{104}$.

Oman's Sohar Port and Free Zone, a deep-water seaport located in the Gulf of Oman in the northwestern part of the country, close to the Oman-UAE border, and its associated FTZ, which is considered one of the world's largest such facilities, is of particular interest to China. Beijing is also interested in Oman's expansion of road networks and a railroad that will link the port of Sohar and the FTZ with the existing transport corridors of Oman and the PG, extending to the UAE and Saudi Arabia $^{105}$.

\section{China - GCC: Energy Cooperation}

China became a net oil importer in 1993, and by the late 1990s, the importance of ME oil in China's dependence on imported oil and for its national energy security had become apparent ${ }^{106}$. In an effort to secure gas and oil supplies, China's state-owned oil companies, with government support, are pursuing a fuel procurement strategy in all energy producing countries, with a focus on developing bilateral ties with selected important countries ${ }^{107}$. In 2014, China overtook the US as the first destination for oil exports from the ME. The China National Petroleum Corporation (CNPC) estimates that China imported about $62 \%$ of its oil reserves in $2016^{108}$. More than half of China's oil imports reach its ports through the Strait of Hormuz, the Strait of Malacca and the South China Sea ${ }^{109}$.

In the PG, the remaining proven oil reserves account for $66 \%$ of the world, oil production - 30\%, export trade - 55\%, natural gas reserves - $36 \%{ }^{110}$. Saudi Arabia ranks first with 35.5 billion tons of proven oil reserves, which is $20 \%$ of the world's reserves. Iran ranks third with 17.2 billion tons, accounting for $10 \%$. Iraq is in fourth place with 15.8 billion tons, occupying $9 \%$. The UAE is ranked $5^{\text {th }}$ with 13.4 billion tons, accounting for $8 \%$. Kuwait is in $6^{\text {th }}$ place with 13.2 billion tons, accounting for $8 \%$. In total, the five countries have 89.8 billion tons of proven oil

\footnotetext{
${ }^{103}$ Fulton 2018d: 186.

${ }^{104}$ Duqm SEZ: Welcome to the Future of Growth, Middle East Policy Council. https://mepc.org/duqm-sez-welcome-future-growth

${ }^{105}$ Zambelis 2015: 13 .

${ }^{106}$ Wu, Wang 2009: 36.

${ }^{107}$ Ziegler 2011: 216.

${ }^{108}$ Fasulo, Talbot 2017: 83.

${ }^{109}$ Garlick, Havlova 2020: 2.

${ }^{110} \mathrm{Hu}$ 2004: 102.
} 
reserves, which is $55 \%$ of the world's reserves. Meanwhile, there is a huge potential for oil and gas resources that needs to be proven in ME. The average production ratio $(\mathrm{R} / \mathrm{P})$ in the Gulf region was 90.1 years by 2004 , well above the global average of 50.9 years ${ }^{111}$.

China imports $40-50 \%$ of the oil it needs from the PG, making the region an important component of its energy security ${ }^{112}$. China's largest source abroad is Saudi Arabia, which accounts for $16 \%$ of imports, as well as Oman (10\%), UAE (4\%) and Kuwait (3\%). As China sought to make liquefied natural gas (LNG) (target of $10 \%$ ) a larger energy source by 2020 , Qatar has also become an important energy source for China ${ }^{113}$. About a third of the natural gas consumed is imported from abroad, of which 34\% comes from Qatar alone, and 5\% imported from Yemen was at risk from the civil war that erupted in $2015^{114}$. PRC is already a rapidly developing chemical market and will play an increasingly important role in the future of the Arab petrochemical industry ${ }^{115}$.

SAUDI ARABIA: Saudi Arabia has consistently been the main regional source of oil, and in recent years has alternated with Russia as China's number one global oil partner ${ }^{116}$. In November 1999, during China's President Jiang Zemin's trip to Saudi Arabia, agreements were signed under which the Saudis opened their oil and markets (except for "upstream" exploration and production) to Chinese investment, and in turn, the Saudi national oil company Saudi Aramco was allowed participate in the "downstream" sector of China's oil refining ${ }^{117}$.

Saudi Arabia's traditional share of the US oil market was a function of the country's "strategic relationship" with the US, but this relationship has weakened, especially after the 9/11 attacks and the war in Iraq. The fact that most of the terrorists were considered Saudis made the Kingdom less attractive for US investment. Consequently, the Saudis increasingly turned to China to recycle some of the huge liquidity that was accumulating in the kingdom from record high oil revenues. As a result, since 2002, supplies of Saudi oil to the US have decreased, while supplies to China have increased ${ }^{118}$.

By 2002, Saudi Arabia had become the leading overseas oil supplier to China, while the Chinese received advanced technology from the Saudis to improve the exploitation of their existing inland oil fields, technologies from which they would normally be excluded from by US regulation relating to the export of dual-use and other strategically sensitive items ${ }^{119}$. In 2019 , China imported US $\$ 40.1$ billion of

\footnotetext{
111 Yang 2004: 122-123.

112 Fulton 2020: 517.

113 Fulton 2019e: 4.

${ }^{114}$ Fasulo, Talbot 2017: 84.

115 Al-Abdullah 2004: 3.

116 Fulton 2020: 517.

${ }^{117}$ Harutyunyan 2008: 48.

118 Harutyunyan 2009b: 83-84.

${ }^{119}$ Pham 2011: 2-3.
} 
crude oil from Saudi Arabia ${ }^{120}$.

Energy cooperation also includes China's assistance to the Saudi nuclear program to build nuclear reactors based on the Sino-Saudi agreement of 2016: the first is to be operational by 2022, and fifteen more by 2032. While officially their goal is peaceful and to provide an alternative energy source to oil, they also have political implications for defending against Iran's nuclear program ${ }^{121}$.

In 2016, China Nuclear Engineering Group Corp (CNEC) signed an agreement with Saudi Arabia to develop its own fourth-generation nuclear technology in Saudi Arabia. The agreement marks an important step towards the export of high-temperature gas-cooled reactors, a domestic nuclear technology jointly developed by CNEC and Tsinghua University. The Chinese company plans to invest about 16.3 billion yuan (US $\$ 2.48$ billion) in a nuclear power equipment industrial cluster and a production base for nuclear graphite, a key material used in high-temperature gas-cooled reactors ${ }^{122}$.

In August 2017, China National Nuclear Corp (CNNC), China's leading state nuclear developer, signed a MoU with the Saudi Geological Survey (SGS) to facilitate further cooperation between the two parties in the exploration and appraisal of uranium and thorium resources. The state-owned Saudi Technology Development and Investment Co (Taqnia) has signed a MoU with China Nuclear Engineering Group Corp to develop desalination projects using gas-cooled nuclear reactors ${ }^{123}$.

In 2017, the Dubai Electricity and Water Authority (DEWA) selected Saudibased ACWA Power and China's Shanghai Power to build a 700 megawatts (MW) extension to the Mohammed bin Rashid Al Maktoum Solar Complex, more than three times the capacity of the original expansion plans. Under the terms of the contract, the new plant will supply electricity at 7.3 US cents per kilowatt-hour $(\mathrm{kWh})$. The project will have the world's tallest solar tower, 260 meters high $^{124}$, and build the world's largest solar power plant at an estimated cost of US \$3.86 billion. It will be phased in starting in 2020 and is part of the Dubai government's commitment to meet $75 \%$ of its energy needs from renewable energy sources by $2050^{125}$. The solar park will produce $5,000 \mathrm{MW}$ by 2030 with an investment of AED 50 billion. On March 24, 2019, DEWA, ACWA Power and SRF announced the financial closure of the forth phase of the $950 \mathrm{MW}$ project ${ }^{126}$.

\footnotetext{
${ }^{120}$ Zishi, Le, Liping 2020: 532.

${ }^{121}$ Garlick, Havlova 2020: 12.

${ }^{122}$ Lyu, Hu 2016: China Nuclear to Bring Nuclear Power to Saudi Arabia, China Daily, January 21.

${ }^{123}$ Saudi Arabia Signs Cooperation Deals with China on Nuclear Energy, Reuters, 25.08.2017.

124 Graves, Everington 2017: Sheikh Mohammed bin Rashid Announces Winning Contract for World's Largest CSP Solar Project, The National, September, 16.

${ }^{125}$ Fulton 2019c: 11.

${ }^{126}$ DEWA ACWA Power, Silk Road Fund Reach Financial Closing on 950mw 4th Phase of Mohammed bin Rashid Al Maktoum Solar Park, The Emirates News Agency, 24.03.2019.
} 
Saudi Arabia also planned to build a solar and carbon black integrated complex worth US \$2 billion in partnership with China's Longi and South Korea's OCI. The feasibility study of the project was planned to be completed by mid$2019^{127}$.

UAE: The UAE is an important partner in the PG, which is one of the top 15 oil importers to the Middle Kingdom and, most importantly, it has access to the ocean, unlike Qatar, bypassing the Strait of Hormuz. The UAE is ready to become China's window to the ME and a "stronghold" in the $\mathrm{PG}^{128}$.

CNPC and its subsidiary Petrochina, as well as the China Petroleum and Chemical Corporation (SINOPEC Group) and its first listed company Sinochem International, operate in the UAE's oil and gas sector. Following the signing of a strategic partnership between the Abu Dhabi State National Oil Company (ADNOC) and CNPC in January 2012, CNPC received a 40\% concession in a joint venture with ADNOC to work on exploration and production projects in the $\mathrm{UAE}^{129}$.

In March 2017, Chinese contractors secured a presence in the local solar industry by joining Jinko Solar in a consortium that struck a 25 -year deal to install a 1,177 MW power plant at Sweihan in Abu Dhabi ${ }^{130}$.

OMAN: By the early 1980s, China began to view Oman not only because of its strategic importance, but also as a country with oil resources. The need to secure long-term energy supplies led China to import oil from Oman in 1983 (Oman became the first Arab nation to export oil to China) and to start purchasing Omani natural gas in $1997^{131}$. About 95\% of Oman's oil exports in September 2015 came to China ${ }^{132}$, which is the world's largest consumer of Oman's oil, accounting for more than half of its oil exports. The Oman Oil Company (OOC) has signed a series of agreements with several Chinese enterprises, including CNBC, Senok and SINOPEC, to develop bilateral industrial zone projects and to build two storage facilities at Xingang Port. China has invested nearly US \$ 600 million in several sectors in Oman, including oil and petrochemicals, and has also financed training for Omani engineers and improving the efficiency of oil production ${ }^{133}$. Since Oman is the largest non-OPEC (Organization of the Petroleum Exporting Countries) oil producer in the ME, China can view Oman's position outside the cartel as a

\footnotetext{
127 Saudi Arabia Plans \$2-billion Solar and Carbon Black Complex, ETEnergyworld.com, 14.01.2019.

${ }^{128}$ OAE gotov stat' oknom Kitaya na BV - ekspert o vizite glavy KNR v OAE i Afriku [The UAE is Ready to become China's Window in the ME - an Expert on the Visit of the PRC Head to the UAE and Africa], Informatsionnyy portal Fars News - Forum Korrespondentov Irana, Tsentral'noy Azii i Rossii, 23.07.2018.

${ }^{129}$ Scott 2015: 12-15.

${ }^{130}$ Fahy 2017: UAE on China's Silk Road Map. The National, March 13.

${ }^{131}$ Chaziza 2019c: 46.

132 Zambelis 2015: 13.

${ }^{133}$ Rakhmat 2014: Exploring the China and Oman Relationship. The Diplomat, May 10.
} 
valuable asset for indirectly influencing OPEC members, many of which are the main sources of oil imports to China, on a number of issues ${ }^{134}$.

In 2017, Ningxia Zhongke Jiaye New Energy and Technology Management Co. signed a MoU with the Omani Investment Fund to build a US \$ 94 million solar panel manufacturing facility in the Dukm Free Zone. It will produce panels for power plants generating 1,000 MW of energy per year. Ningxia Zhongke will hold $51 \%$ of the shares and the remaining $49 \%$ will be held by the Omani Investment Fund ${ }^{135}$. Oman already exports more than three-quarters of all its oil and condensate to China ${ }^{136}$.

KUWAIT: Sino-Kuwaiti relations in the energy sector are developing quite actively, which until recently was hindered by the absence in Kuwait of a law allowing foreign companies to finance oil production. Nevertheless, the SINOPEC managed to reach an agreement in principle with the Kuwaiti side on participation in financing the development of oil reserves in northern Kuwait, which are estimated at 10 billion barrels. In 2004, Kuwait and China signed an agreement on cooperation in the oil and gas sector, and in December 2005 - an agreement on investments in the oil refining and petrochemical industry of Guangdong province $^{137}$.

BAHRAIN: China-Bahrain trade volume increased to US $\$ 1.6$ billion in 2019 , a rise from the US $\$ 1.3$ billion in 2018. By 2020, about 600 Chinese companies were registered in Bahrain, and the total investment has increased from US \$ 50 million to US \$ 400 million. In 2010, the Bahrain-China Joint Investment Forum (BCJIF) was established to foster economic ties between the two countries, and 18 Chinese commercial agencies, including the BOC, opened operations in Bahrain. In October 2019, the Bahraini Al-Waha Fund invested in Beijing-based MSA Capital, ${ }^{*}$ its first investment in a Chinese fund. US \$ 250 million in Chinese funds made ten investments in the Gulf region by 2020, facilitating exchanges between Chinese and Bahraini entrepreneurs. PRC investment and construction in Bahrain reached US \$ 1.4 billion from 2013 to 2019, most of which is in utilities (US \$ 730 million) and real estate (US \$ 690 million) $)^{138}$.

\footnotetext{
${ }^{134}$ Zambelis 2015: 12-13.

${ }^{135}$ Capturing the Opportunities from Belt and Road Initiative. 2018: 22.

${ }^{136}$ Molavi 2018: Enter the Dragon: China's Belt and Road Rising in the Middle East, The Caravan, Issue 1819, Hoover Institution or Stanford University, October 02.

${ }_{137}$ Deych 2008: Afrika v strategii Kitaya [Africa in China's Strategy], Institut Afriki RAN, Moskva, 222-223.

* MSA Capital, founded in 2014, is an independent global private equity and venture capital firm with over US \$ 1.5 billion under management. It manages the capital of the world's leading sovereign wealth funds, international asset managers, pension funds, university donations, family office funds, as well as leading Chinese new economy entrepreneurs. It actively collaborates with prominent entrepreneurs in China and other technology markets to create leading innovative companies aiming to generate significant financial returns and meaningful positive impact. The firm is headquartered in Beijing with resident teams in Shanghai, Singapore, MENA and the USA.

${ }^{138}$ Chaziza 2020a: 75.
} 
QATAR: With 25 trillion cubic meters, Qatar has the third largest natural gas reserves in the world and is the world's largest exporter of LNG with an annual production of 77 million tonnes and is projected to grow to 110 million tonnes a year by $2024^{139}$. Energy is the cornerstone of bilateral cooperation. Qatar is the second largest exporter of LNG. Here, Qatar's strategic importance to China's energy security will be determined by Qatar's uninterrupted supply of natural gas to meet China's growing energy demand ${ }^{140}$. In 2020 , the Chinese side signed a US $\$ 3$ billion contract with Qatari partners for the LNG carrier project ${ }^{141}$.

\section{Conclusion}

China and the GCC countries favor a faster pace of economic rather than political reform. Among the important areas of economic cooperation between the PRC and the states of the region are infrastructure construction, energy, including nuclear, space exploration, communications, as well as finance and investment.

Economic relations between China and the GCC countries are dominated by oil, because despite the diversification of oil sources to support a thriving Chinese economy, the Gulf occupies an irreplaceable strategic position due to the high quality of oil, ease of transportation and low oil production costs. After the GCC countries opened their relatively closed and monopolized oil exploration and production market to new players in order to balance the US in oil production and diversify their oil exports, Chinese companies received contracts for the production of oil or gas. With the expected increase in the number of energy deals and the completion of large-scale energy projects under the BRI, China's energy concerns could ease, helping to support economic growth.

China is also emerging as a major importer of LNG, which will create new market opportunities for GCC producers. GCC offers price advantages for raw materials as well as a strategic location on major trade routes to Asia. The GCC countries also have a huge oilfield services market, and China is already a booming chemical market, playing an increasingly important role in the Arab petrochemical industry. They are most interested in China's vibrant labor market, which has a large surplus of labor, and in goods that the country can produce cheaply, such as textiles.

Energy is supplied from the Persian Gulf to China, mainly through maritime communication channels and "Choke Points", the safe passage of which Beijing seeks to ensure as part of the "Gulf String of Pearls" strategy. Its goal is to facilitate effective resource allocation and deep market integration, economic policy

\footnotetext{
${ }^{139}$ Shoeb 2019: Belt \& Road Initiative to Bring Qatar and Mideast Closer to the World: QFZA Chief, The Peninsula, November 04.

${ }^{140}$ Chaziza 2020b: 86.

${ }^{141}$ He 2020: Qatar and China Natural Partners in Belt and Road Cooperation, The Peninsula, June 30; China and Qatar are Natural Partners in Belt and Road Co-Operation: Envoy, Gulf Times, 29.06.2020.
} 
coordination, and deepening open, inclusive, balanced economic cooperation in the region. The GCC countries prefer the expansion of infrastructure and production equipment in high-tech industries. The GCC engineering market accounts for $19 \%$ of the world market, which provides great opportunities for Chinese companies currently cooperating in the construction of high-speed railways, electricity and ports. The "Two Wheel" and "Two Wing" strategies will enable the establishment of business clusters in Chinese industrial parks (FTZ) in the GCC countries, increase trade flows and connect supply chains throughout the region.

While parts of the BRI vision align well with the GCC's current goals in the areas of economic diversification, energy, investment, market access, and regional security, other aspects of the initiative carry risks, including BRI's engagement with regional competitors in the GCC. Impending FTA negotiations between China and the GCC countries are expected to diversify China's oil imports and help GCC nations reduce US dominance in the region. Besides, the stable growth of the Chinese economy, the growing cooperation of the PRC with the GCC countries raises may concern the US about the loss of its weight in world politics and, in particular, the loss of influence in the PG region. To achieve the BRI's trade and infrastructure goals and ensure a continuous flow of diversified energy supplies, China needs to strengthen its relationship with both regional centers, without alienating either of them or the US.

\section{BIBLIOGRAPHY}

Al-Abdullah A. Y. 2004: Sino-Arab Energy Cooperation, A Presentation Collection for Seminar on "International Energy Security and Cooperation", SIIS Publication, Shanghai, June 24-25, 1-10.

Aguinaldo J. 2017: Kuwait Awards Runway Construction Package, Middle East Business Intelligence (MEED), March 29.

The Asian Infrastructure Investment Bank (AIIB) Headquarters, Beijing. https://www.aiib.org/en/about-aiib/governance/members-of-bank/index.html

Bahrain Economic Vision 2030, Ministry of Industry, Commerce and Tourism, Kingdom of Bahrain. https://www.moic.gov.bh/en/Ministry/bahrain-economic-vision-2030

Batyrshin I.M. 2006: Mesto stran Soveta sotrudnichestva arabskikh gosudarstv persidskogo Zaliva na menyayushchemsya rynke nefti [The Place of the Cooperation Council Countries of the Arab States of the Gulf in the Changing Oil Market], Vostokovednyy Sbornik, Institut Blizhnego Vostoka, Moskva, 321-338 (in Russian).

Bhaya A. G. 2018: Analysis: Could China-funded Omani Port Go against Beijing's Interest? CGTN, February 27.

Blanche Ed. 2017: China's New Silk Road Includes Both Risk and Promise of Prosperity, The Arab Weekly, December 17.

Capturing the Opportunities from Belt and Road Initiative. 2018: HSBC Commercial Bank International Cables Federation 2018, HSBC Bank (China) Company Limited, 27. 
Carey G., Nereim V., Cannon Ch. 2017: Sun, Sea and Robots: Saudi Arabia's Sci-Fi City in the Desert, Bloomberg, October 26.

Chaziza M. 2020a: China-Bahrain Relations in the Age of the Belt and Road Initiative, Strategic Assessment, The Institute for National Security Studies (INSS), Vol. 23, No. 4, October, 68-83.

Chaziza M. 2020b: China-Qatar Strategic Partnership and the Realization of One Belt, One Road Initiative, China Report, SAGE Journals, No. 56 (1), February, 78-102.

Chaziza M. 2019c: The Significant Role of Oman in China's Maritime Silk Road Initiative, Contemporary Review of the Middle East, No. 6 (1), 44-57.

Chen D., Han, W. 2019: Deepening Cooperation between Saudi Arabia and China, King Abdullah Petroleum Studies and Research Center (KAPSARC), March, 32.

China and Qatar are Natural Partners in Belt and Road Co-Operation: Envoy, Gulf Times, 29.06.2020.

China and the Persian Gulf, Wilson Center, 12.07.2010.

China-GCC FTA, China FTA Network. http://fta.mofcom.gov.cn/topic/ engcc.shtml

China's 'Belt and Road' Offers Middle East Opportunities Galore, Ameinfo.com, 19.06.2017.

The Cooperation Council for the Arab States of the Gulf (GCC), Ministry of Foreign Affairs, the People's Republic of China, 15.11.2000.

DEWA ACWA Power, Silk Road Fund Reach Financial Closing on 950mw 4th Phase of Mohammed bin Rashid Al Maktoum Solar Park, The Emirates News Agency, 24.03.2019.

Deych T.L. 2008: Afrika v strategii Kitaya [Africa in China's Strategy], Institut Afriki RAN, Moskva, 326 (in Russian).

Dos Santos G. P. 2015: The United Arab Emirates, Africa and Angola in the new Silk Road, IPRIS Viewpoints, Portuguese Institute of International Relations and Security (IPRIS), July 03, 4.

Duqm SEZ: Welcome to the Future of Growth, Middle East Policy Council. https://mepc.org/duqm-sez-welcome-future-growth

Ekonomika Odnogo Poyasa, Odnogo Puti. Vozmozhnosti i riski transportnykh koridorov. 2020: [Economy of One Belt, One Road. Opportunities and Risks of Transport Corridors], World Bank Group, Washington DC, 167 (in Russian).

Fahy M. 2017: UAE on China's Silk Road Map. The National, March 13.

Fasulo F. Talbot, V. 2017: The MENA Region: Where the Belt Joins the Road, China's Belt and Road: A Game Changer? Edited by Alessia Amighini, the Italian Institute for International Political Studies (ISPI), 75-97.

From Regional Pioneer to Global Contender: The Economic Vision 2030 for Bahrain, Bahrain.Bh. https:/www.bahrain.bh/wps/wcm/connect/38f53f2f-9ad6-423d-9c962dbf17810c94/Vision\%2B2030\%2BEnglish\%2B\%28low\%

2Bresolution\%29.pdf?MOD=AJPERES

Fulton J. 2019a: China Deepens Ties with UAE with Industrial Investment, Al-Monitor, July 10,12 .

Fulton J. 2019b: China's Changing Role in the Middle East, Atlantic Council. Rafik Hariri Center for the Middle East, June, 19.

Fulton J. 2019c: Domestic Politics as Fuel for China's Maritime Silk Road Initiative: The Case of the Gulf Monarchies, Journal of Contemporary China, Taylor and Francis Group, July 04, 175-190. 
Fulton J. 2019d: The Gulf between the Indo-Pacific and the Belt and Road Initiative, Rising Powers Quarterly, Rising Powers in Global Governance, Vol. 3, Issue 2, August, 175-193.

Fulton J. 2019e: China in the Gulf, About Energy, November 04, 1-8.

Fulton J. 2020: China-Saudi Arabia Relations Through the ' $1+2+3$ ' Cooperation Pattern, Asian Journal of Middle Eastern and Islamic Studies, Shanghai International Studies University, Taylor and Francis Group, Vol. 14, No. 4, 516-527.

Garlick J., Havlova R. 2020: China's 'Belt and Road' Economic Diplomacy in the Persian Gulf: Strategic Hedging Amidst Saudi-Iranian Regional Rivalry, Journal of Current Chinese Affairs, 24.

Graves L., Everington J. 2017: Sheikh Mohammed bin Rashid Announces Winning Contract for World's Largest CSP Solar Project, The National, September 16.

Harutyunyan Agh. 2009a: Around China's Relations with the Gulf Cooperation Council (GCC), Sbornik dokladi ot Pŭrva Natsionalna nauchna konferentsiya "Kitaĭ: traditsiya i sŭvremennost”, Institut Konfutsiū, Sofiya, 157-167.

Harutyunyan Agh. 2008: Ch'in-saudyan haraberut'yunneri zargats'umy sksats 1980akannerits' [The Development of Sino-Saudis Relations Since 1980-s], «Merdzavor Arevelk' yev Kovkas» Mijazgayin gitazhoghov nvirvats Arevelagitut'yan instituti himnadrman 50-amyakin, noyemberi 5-6, 2008, Zekuyts'neri t'ezer, HH GAA AI, Yerevan, 47-49 (in Armenian).

Harutyunyan Agh. 2009b: Ch'in-saudyan razmavarakan hamagortsakts'ut'yan shurj [On the Sino-Saudi Strategic Cooperation], Arevelaasiakan usumnasirut'yunner, H. 1, HH GAA AI, Yerevan, 72-91 (in Armenian).

Harutyunyan Agh. 2019: On Some Obstacles and Challenges to the Implementation of the Chinese Initiative One Belt, One Road, Orbis Linguarum, Езиков свят, Филологическия факултет при ЮЗУ 'Неофит Рилски', Благоевград, България, Vol. 17, Issue 2, 143-156.

Harutyunyan Agh. 2020: Middle East and North Africa as a Part of Chinese String of Pearls Strategy, Orbis Linguarum, Езиков свят, Филологическия факултет при Ю3У 'Неофит Рилски', Благоевград, България, Vol. 18, Issue 3, 60-71.

Harutyunyan Agh. 2021: China's One Belt, One Road Initiative in the Middle East and North Africa, IOS NAS RA, Yerevan, "Gitutyun”, 534.

He Zh. J. 2020: Qatar and China Natural Partners in Belt and Road Cooperation, The Peninsula, June 30.

Herlevi A. A. 2016: China and the United Arab Emirates: Sustainable Silk Road Partnership? China Brief, The Jamestown Foundation, Vol. 16, Issue 2, January 26, 13-17.

Hollingsworth J. 2017: How the Gulf Row is Blocking China's New Silk Road, South China Morning Post, June 05.

Huang J. 2017: Qatar Crisis Poses Test for China's Belt \& Road Project, Voice of America (VOA), June 08.

Hu Jianyi 2004: Energy Development in China and Its Cooperation with the Gulf Area, A Presentation Collection for Seminar on "International Energy Security and Cooperation", June 24-25, SIIS Publication, Shanghai, 100-104.

Kazem H. A., Chaichan M. T., Al-Waeli A. H., Bin Sopian K. 2020: Oman Vision 2040: Renewable Energy Program, Researchgate.net, Newsletter, Vol. 1, Issue 1, September 7 . 
In Its Promotional Campaign in China, Duqm Focuses on Attracting New Industrial Companies, SEZAD - Sultanate of Oman, 24.09.2018.

Juan Ch., Meng Sh., Wen Sh. 2018: Aligning China's Belt and Road Initiative with Saudi Arabia's 2030 Vision. Opportunities and Challenges, China Quarterly of International Strategic Studies, Vol. 4, No. 3, November, 363-379.

Karasik Th. 2018: Chinese President's Visit to the UAE and Africa Demonstrates a Shift in the New World Order", Arab News, July 29.

Kazem H. A., Chaichan M. T., Al-Waeli A. H., Sopian K. B. 2020: Oman Vision 2040: Renewable Energy Program, Researchgate.net, Newsletter, Vol. 1, Issue 1, September 7.

King's Visit to China Reflects Saudi Arabia's Position Globally, Experts Say, Arab News, 19.03.2017.

Kitay rasshiryayet vliyaniye na Blizhnem Vostoke i zakreplyayetsya $v$ Afrike [China Expands Influence in the Middle East and Consolidates in Africa], Informatsionnyy portal Fars News - Forum Korrespondentov Irana, Tsentral'noy Azii i Rossii, 23.07.2018 (in Russian).

Korybko A. 2017: Why is China Choosing to Partner with Israel and Saudi Arabia? The Duran, March 25.

Lee H. L. 2017: Abu Dhabi Ports Inks \$300m Investment Cooperation with China, Seatrade Maritime News, July 21.

Lokhande S. A. 2017: China's One Belt One Road Initiative and the Gulf Pearl Chain, China Daily, June 05.

Lyu Ch., Hu M. 2016: China Nuclear to Bring Nuclear Power to Saudi Arabia, China Daily, January 21.

Mashin V.V., Yakovlev A.I. 1985: Persidskiy Zaliv v Planakh i Politike Zapada [The Persian Gulf in the Plans and Politics of the West], Moskva, 212 (in Russian).

Melkumyan Ye. S. 2006: Sovet Sotrudnichestva Arabskikh Gosudarstv Zaliva: Regional'nyye i Global'nyye Vyzovy [Cooperation Council for the Arab States of the Gulf: Regional and Global Challenges], Sbornik statey, Blizhniy Vostok i Sovremennost', Moskva, 92-102 (in Russian).

Miles D., Edwards, B. The New Silk Road. Investing in and Venturing with Middle Eastern Companies, Remark. Latham and Watkins, 15.

Mo Ch. 2011: Exploring Economic Relations between China and the GCC States, Journal of Middle Eastern and Islamic Studies (in Asia), Shanghai International Studies University, Taylor and Francis Group, Vol. 5, No. 4, 88-105.

Molavi A. 2018: China and the GCC States - A Turbo-Charged Trade Relationship, The New Silk Road Monitor, October 29.

Molavi A. 2018: Enter the Dragon: China's Belt and Road Rising in the Middle East, The Caravan, Issue 1819, Hoover Institution or Stanford University, October 02.

Murphy D. 2019: The UAE Signed a Massive, $\$ 3.4$ billion Deal with China - and That 'Isn't a Surprise', CNBC, April 29.

New Choice: Chinese Currency Expands to Middle East, Sputnik, 06.06.2015.

OAE gotov stat' oknom Kitaya na BV - ekspert o vizite glavy KNR v OAE i Afriku [The UAE is Ready to become China's Window in the ME - an Expert on the Visit of the PRC Head to the UAE and Africa], Informatsionnyy portal Fars News Forum Korrespondentov Irana, Tsentral'noy Azii i Rossii, 23.07.2018 (in Russian). 
Oman Vision 2040, Omanuna: The official E-Government Services Portal. https://omanuna.oman.om/en/home-top-level/eparticipation/oman-vision-2040

Pham J. P. 2011: China's Interests in the Middle East and North Africa in the Light of Recent Developments in those Regions, Testimony before the U.S.-China Economic and Security Review Commission Hearing on "China's Current and Emerging Foreign Policy Priorities", Atlantic Council, April 13, 10.

Qatar National Vision 2030. 2008: General Secretariat for Development Planning, Doha, July 33.

Rakhmat M. Z. 2014: Exploring the China and Oman Relationship, The Diplomat, May 10 .

Al Saadi A. S. 2012: The Origins of Omani-China Friendship: A Historical Review, Journal of Middle Eastern and Islamic Studies (in Asia), Shanghai International Studies University, Taylor and Francis Group, Vol. 6, No. 2, 84-105.

Saidi N. H. 2014: The Gulf Should Pivot East and Build the 'New Silk Road', HuffPost News, April 15.

Saudi Arabia Plans \$2-billion Solar and Carbon Black Complex, ETEnergyworld.com, 14.01.2019.

Saudi Arabia Signs Cooperation Deals with China on Nuclear Energy, Reuters, 25.08.2017.

Scott E. 2015: "China's 'One Belt, One Road' Strategy Meets the UAE's Look East Policy”, China Brief, Vol. 15, Issue 11, The Jamestown Foundation, May 29,12-15.

Shepard W. 2017: Next Up on China's Maritime Silk Road: Abu Dhabi, Forbes, July 02.

Shoeb M. 2019: Belt \& Road Initiative to Bring Qatar and Mideast Closer to the World: QFZA Chief, The Peninsula, November 04.

Spotlight: Belt and Road Set to Boost Development in Mideast, Africa, Xinhua Net, 24.08.2017.

Spotlight: China's 'Belt and Road' Initiative Boosts Mideast Development, English.news.cn, 19.01.2016.

Wang J. 2017: 'One Belt One Road': A Vision for the Future of China-Middle East Relations, Al Jazeera Centre for Studies, May 09, 6.

Wang M. 2018: China's One Belt, One Road Initiative, SOAS University of London, June 01 .

Wang Yi. 2018: China and Arab States Should Jointly Forge the Cooperation Layout Featuring 'Industrial Park-Port Interconnection, Two-Wheel and Two-Wing Approach', Embassy of the PRC in the Republic of Malta, July 10.

Why Qatar Matters to China, in Spite of Gulf Isolation, South China Morning Post, 07.06.2017.

Wu L., Wang Y. 2009: Comparative Analysis of China's Energy Activities in the Middle East and Africa, Journal of Middle Eastern and Islamic Studies (in Asia), Shanghai International Studies University, Taylor and Francis Group, Vol. 3, No. 1, 36-51.

Wu S. 2015: The Strategic Docking between China and Middle East Countries under the 'Belt and Road' Framework, Journal of Middle Eastern and Islamic Studies (in Asia), Shanghai International Studies University, Taylor and Francis Group, Vol. 9, No. 4, 13.

Yang G., 2004: Sino-Middle East Energy Relations and Mutual-benefiting Cooperation, A Presentation Collection for Seminar on "International Energy Security and Cooperation”, SIIS Publication, Shanghai, China, June 24-25, 120-132. 
Zishi Y., Le D., Liping D. 2020: The China-Saudi Arabia (Jizan) Industrial Park under the Belt and Road Initiative, Asian Journal of Middle Eastern and Islamic Studies, Shanghai International Studies University, Taylor and Francis Group, Vol. 14, No. 4, 528-537.

Zambelis, Ch. 2015: China and the Quiet Kingdom: An Assessment of China-Oman Relations, China Brief, The Jamestown Foundation, Vol. 15, Issue 22, November $18,11-15$.

Ziegler, C. E 2011: The Energy Factor in China's Foreign Policy, Seeking Changes. The Economic Development in Contemporary China, Central Compiliation and Translation Press, 206-235.

Aghavni Harutyunyan Institute of Oriental Studies of NAS RA aghavni.harutyunyan1@gmail.com

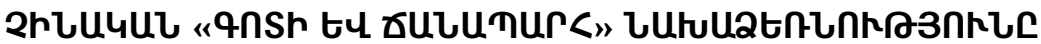

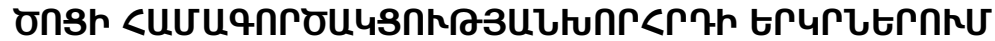

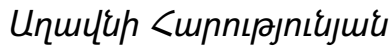

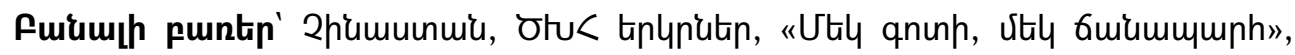

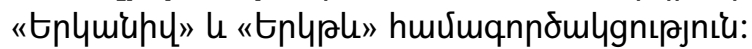

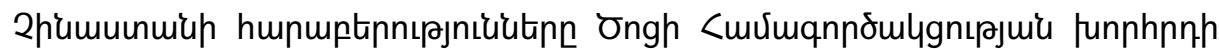

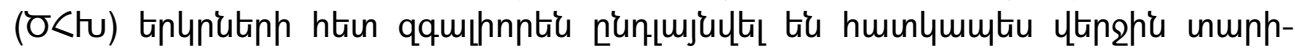

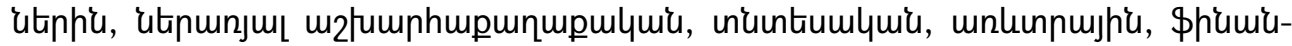

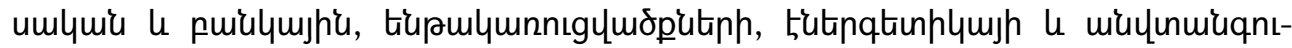

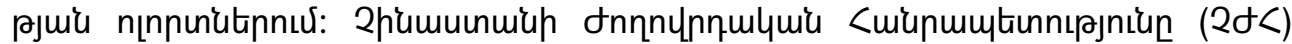

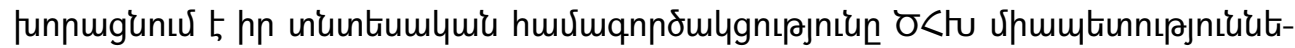

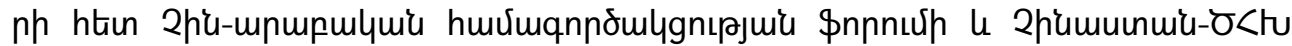

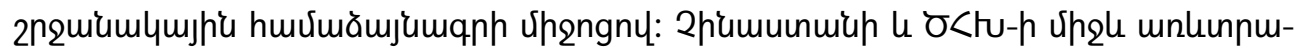

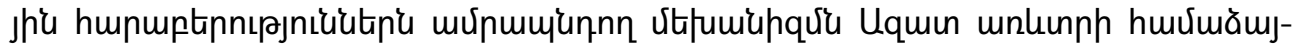

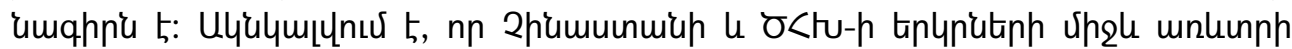

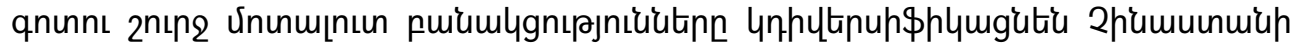

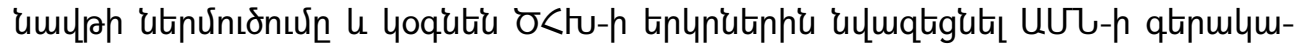

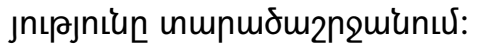

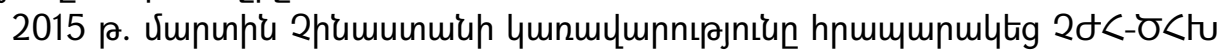

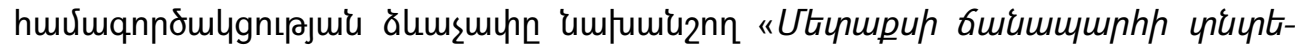

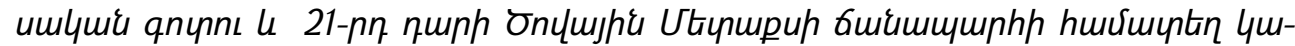

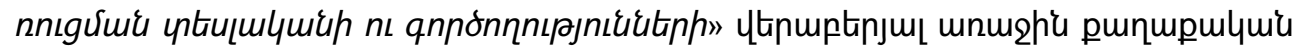

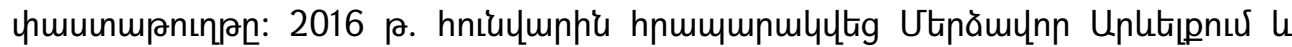

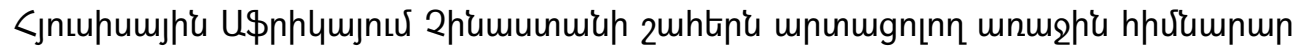

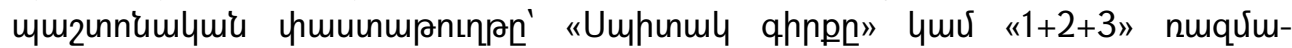




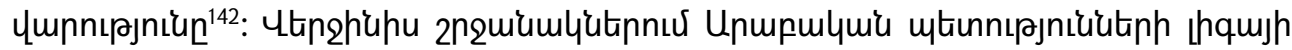

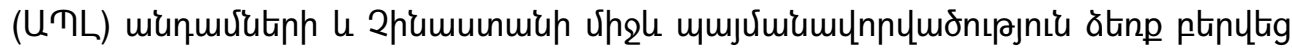

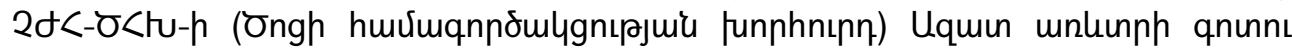

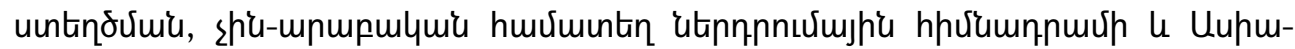

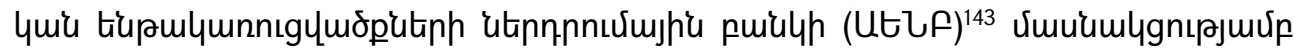

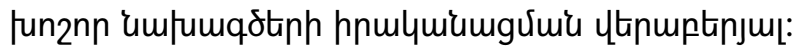

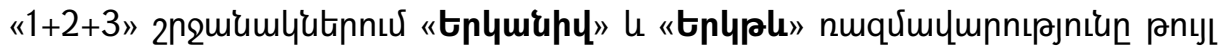

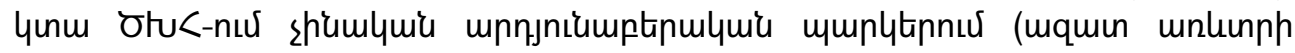

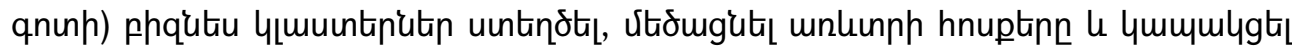

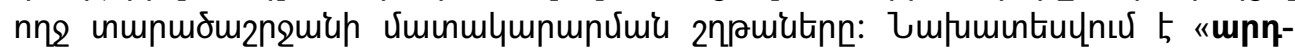

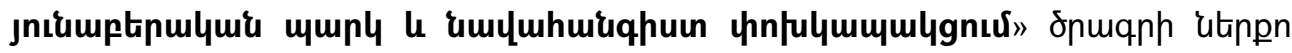

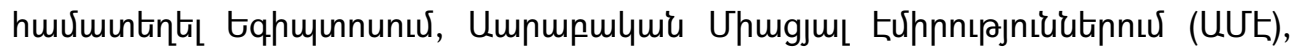

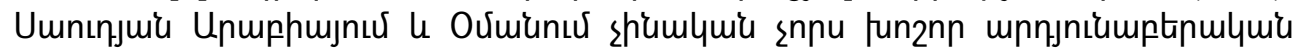

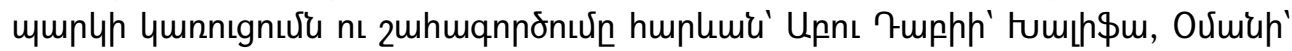

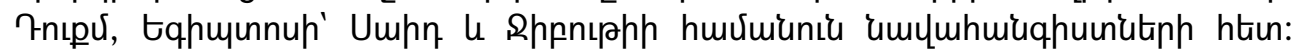

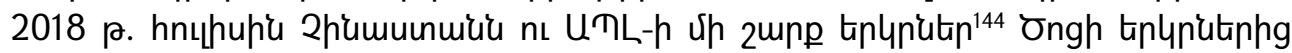

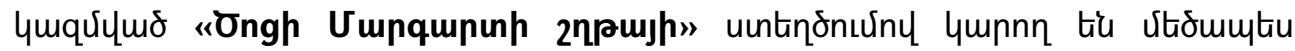

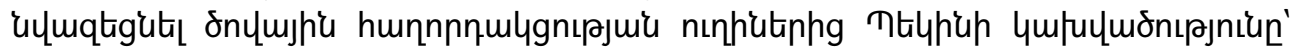

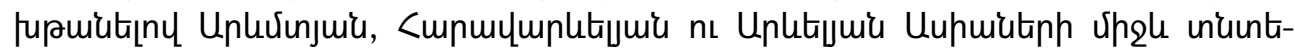
umlymu puuntiqnughn'u qnnonupugutinn:

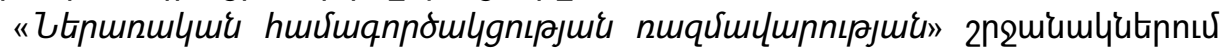

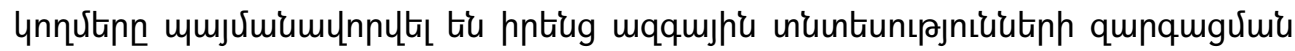

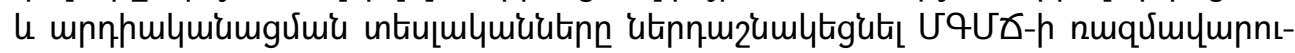

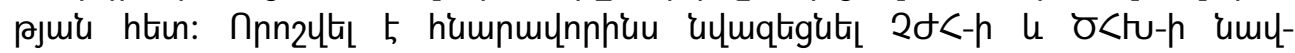

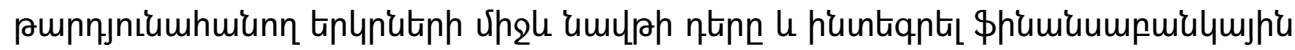

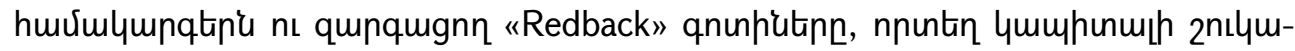

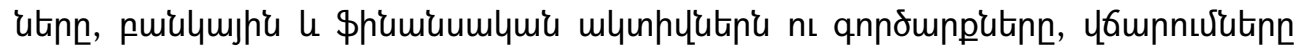

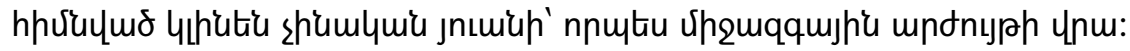

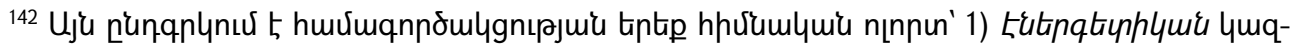

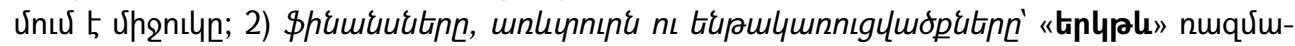

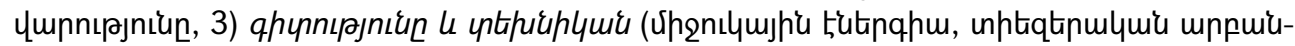

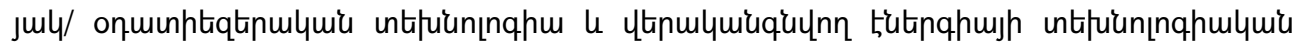

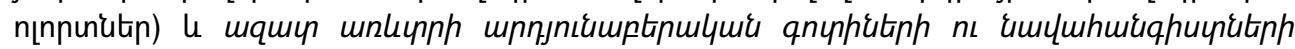

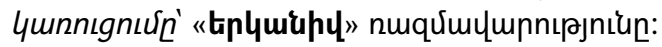

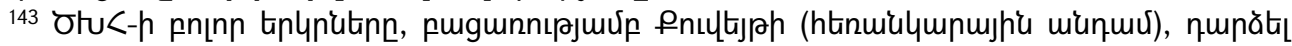

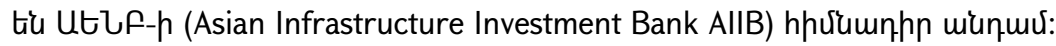

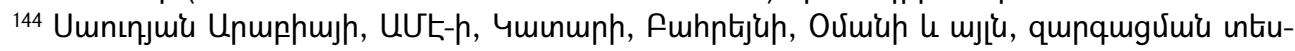

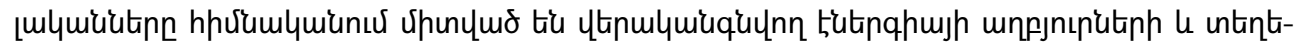

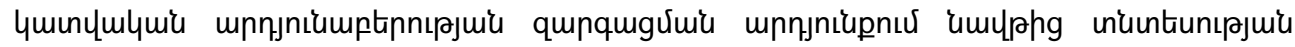

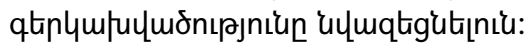




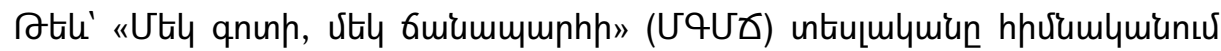

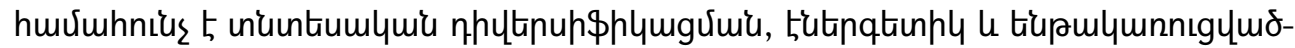

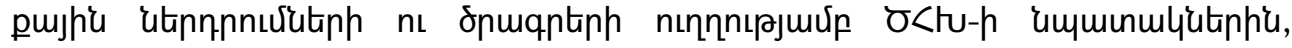

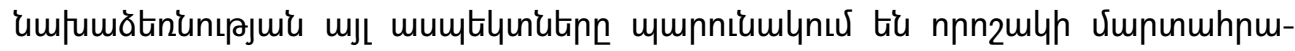

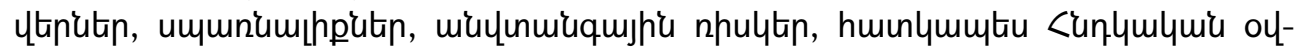

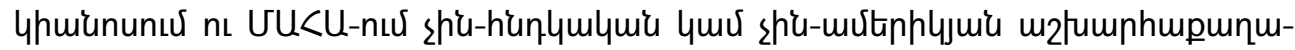

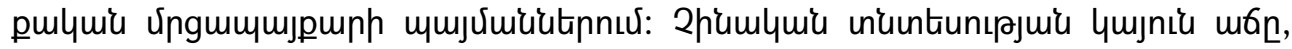

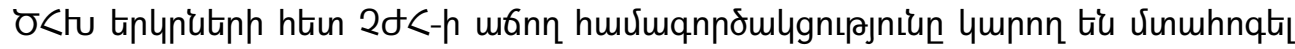

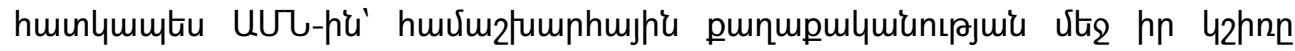

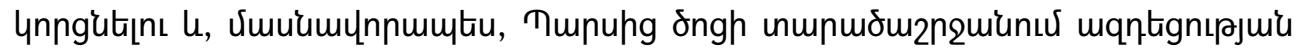

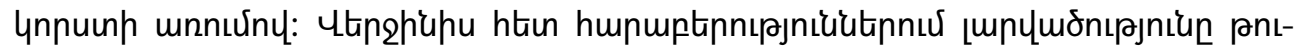

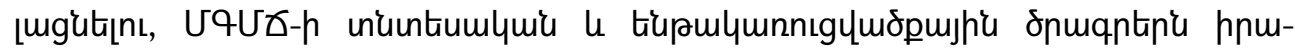

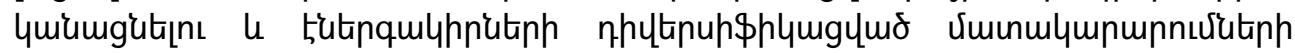

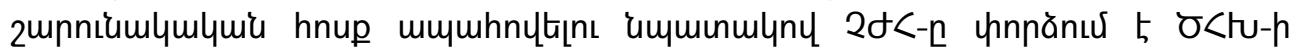

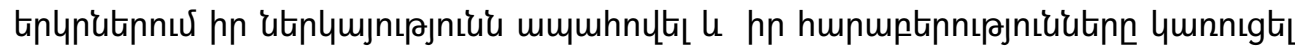

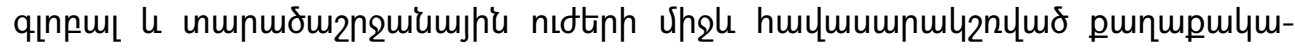
unıpjuiu z'unphhy: 